\title{
The Practice of Transformational Management and its Role in Achieving Institutional Excellence from the Point of View of Workers in the Directorates of Education in Hebron
}

\author{
Dr. Sameer S. Aljamal \\ Istiqlal University/Palestinian Academy for Security and Military Sciences \\ Hebron, Palestine \\ Email: sameeraljamal@yahoo.com
}

Received October, 2017; Accepted January, 2018

\begin{abstract}
The study aims to identify the practice of transformational management and its role in achieving institutional excellence. Primary data was collected from employees working in the Directorates of Education in Hebron governorate. The research methodology includes a multi-item questionnaire survey collected from a sample of 103 employees. The results show that that the average of the mean received on all items on the transformation leadership construct is 3.15 with a verbal interpretation of "average". The highest rated dimension within transformational management is intellectual simulation, followed by inspirational motivation, idealized influence and finally individualized consideration. As for the statements, managers scored high in terms of providing incentives to employees to change, motivating and encouraging them, taking care of their individual differences, communicating with them, addressing their difficulties with courage, giving their employees time to listen to their ideas, and stimulating their thoughts. However, managed scored low in terms of dealing satisfactorily with the workers to promote respect, simulating challenges, trusting everyone, and delegating responsibilities. As for the degree of institutional excellence, the results show an average score. The highest areas within institutional excellence is leadership excellence, followed by service delivery excellence, and finally human excellence. Furthermore, managers are continuously seeking to excel in delivering service to the public. Finally, the results indicate that the staff did not receive an appropriate remuneration based on their evaluation and performance, and the institution did not provide opportunities for their distinguished employees.
\end{abstract}

Keywords: Transformational Management; Institutional Excellence; Employees in the Directorates of Education; the Directorate of Education.

Type: Research paper

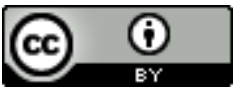

This work is licensed under a Creative Commons Attribution 4.0 International License.

\section{DOI: 10.51325/ijbeg.v1i1.12}

$$
\text { ف فمارسة الإدارة التحويلية ودورها في تحقيق التميز المؤسدي من وجهة نظر العاملين في مديريات التربية التعليم }
$$


أعلى مجالات ممارسة الإدارة التحويلية كان استثارة التفكير، ثم الحفز الإلهامي، ثم التأثير المثالي وأخيراً مجال

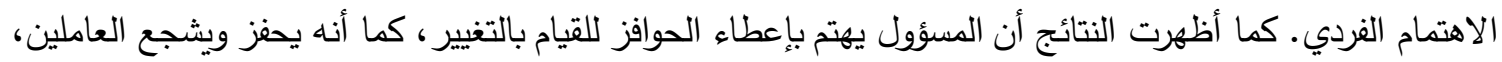
ويراعي الفروق الفردية بينهم، ويحافظ على التواصل والاتصال معهم، ويتصدى للمصاعب بشجاعة، ويعطي الوقت

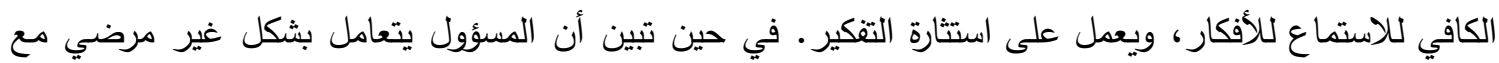

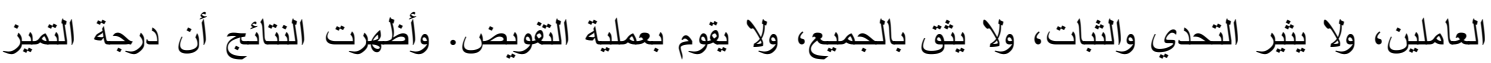

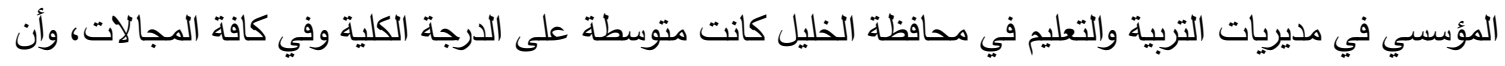

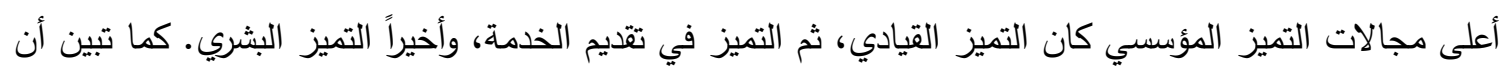

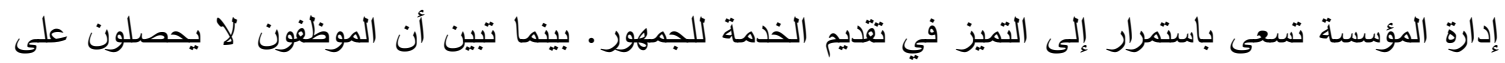
مكافآت تتاسب تقييمهم، ولا تتيح المؤسسة فرص ابتعاث الموظفين المتميزين لديها.

الكلمات المفتاحية: الإدارة التحويلية، التميز المؤسسي، العاملين في مديريات التربية والتعليم، مديرية التربية والتعليم.

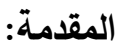

يتوقف نجاح هذه المؤسسات أو فثلها على مدى النجاح الذي يحققه القادة الإداريون في أعمالهم، من خلال تأديتهم

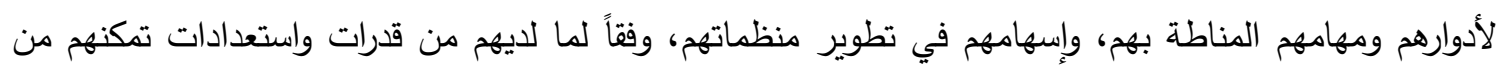

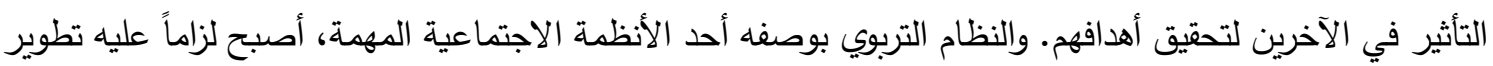

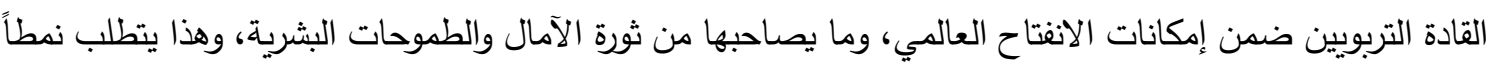

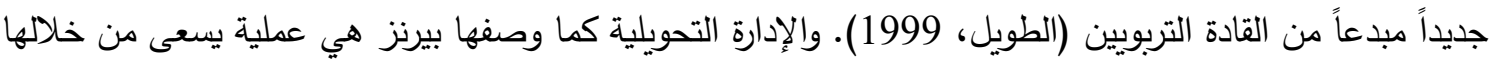

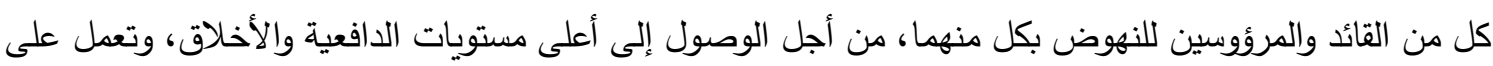

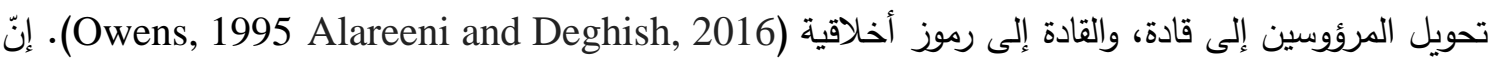
تطوير المؤسسات التربوية يتطلب وجود مسؤولين يمتلكون مهارات قيادية، تُكنُهم من تأديةِ أدوارهم ومهماتهم خير

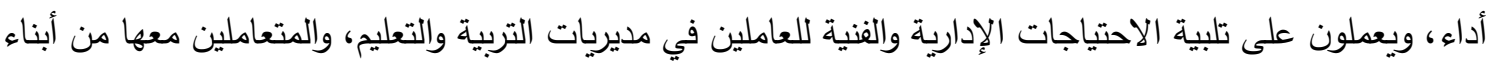

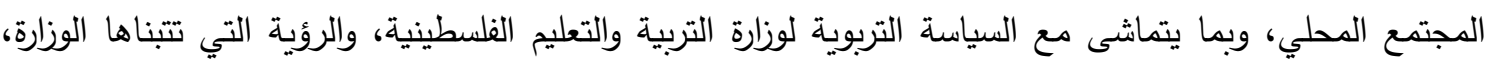
والمتمثلة في إعادةً تثكيل الأنموذج التربوي الذي يركز على استراتيجيات القيادة والإدارة، القائمة على الاستخدام الأمثل لما توفره المعلوماتية والتكنولوجيا المعاصرة من وسائل تطوير للإدارة التربوية. مشكلة الدراسة وأسئلتها: لقد تحول دور المديرين من الدور الرقابي إلى دور المسهل، وخلق رؤية مشتركة وشاملة للمنظمة كما يشجع على المشاركة في صنع القرار، والتعاون بين أفراد المنظمة مما ينعكس على شعورهم بالمسؤولية. حيث أثبتت الدراسات أن هناك ثمة علاقة بين خصائص المنظمة المتعلمة وتحقيق الإبداع والتميز المؤسي. حيث لا يمكن أن يتحقق التميز المؤسسي دون أن يكون العاملين داخل المؤسسة راضين عن أعمالهم ومندمجين في أعمالهم، وعليه يمكن تحديد مشكلة الدراسة من خلال الإجابة على السؤال الرئيس الآتي:

السؤال الرئيس: ما درجة ممارسة الإدارة التحويلية ودورها في تحقيق التميز المؤسسي من وجهة نظر العاملين في مديريات التربية والتعليم في محافظة الخليل؟، وينبثق عنه الأسئلة الفرعية الآتية: 1. ما درجة ممارسة الإدارة التحويلية من وجهة نظر العاملين في مديريات التربية والتعليم في محافظة الخليل؟ التئه التئية 
2. ما درجة التميز المؤسي من وجهة نظر العاملين في مديريات التربية والتعليم في محافظة الخليل؟. فرضيات الدراسة:

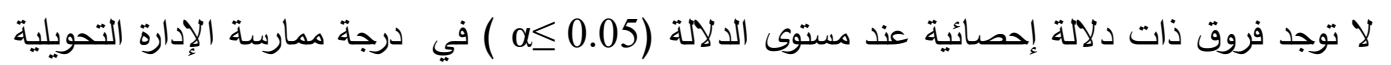
ودورها في تحقيق التميز المؤسسي من وجهة نظر العاملين في مديريات التربية والتعليم في محافظة الخليل

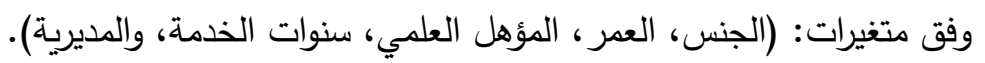

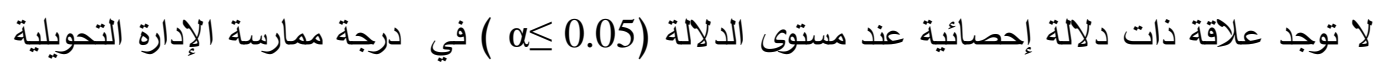
وتحقيق التميز المؤسسي من وجهة نظر العاملين في مديريات التربية والتعليم في محافظة الخليل.

$$
\text { أهداف الدراسة: }
$$

1

2

3 أثر بعض المتغيرات على ممارسة الإدارة التحويلية ودورها في تحقيق التميز المؤسي في فئيز مديريات التربية

والتعليم في محافظة الخليل.

4 مدى وجود علاقة بين ممارسة الإدارة التحويلية وتحقيق التميز المؤسسي في مديريات التربية والتعليم في

محافظة الخليل.

أهمية الاراستة:

يمكن تلخيص أهمية هذه الدراسة بما يأتي:

1

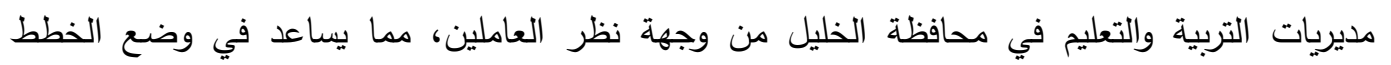

$$
\text { والاستراتيجيات وبرامج التدريب الملائمة. }
$$

2 نتائج الدراسة تفيد المسؤولين في التعرف على مستوى التميز في مديريات التربية والتعليم، للخروج بالتوصيات

اللازمة للوصول إلى مستوى عال من التميز المؤسسي.

3 هذه الدراسة تعد من الدراسات الأولى في فلسطين -على حد علم الباحث- والتي تتتاول ممارسة الإدارة

التحويلية ودورها في تحقيق التميز المؤسسي من وجهة نظر العاملين في مديريات التربية والتعليم، مما قدات

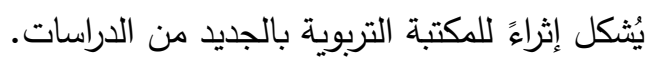

حدود الاراسة:

تتحدد حدود هذه الدراسة بما يأتي:

الحدود الموضوعية: تتناول الدراسة ممارسة الإدارة التحويلية ودورها في تحقيق التميز المؤسسي من وجهة

نظر العاملين في مديريات التربية والتعليم في محافظة الخليل.

الحدود المكانية: تمت هذه الدراسـة على العاملين في مديريات التربية والتعليم في محافظة الخليل: (مديرية

شمال الخليل، مديرية الخليل، مديرية جنوب الخليل، مديرية يطا). 


$$
\text { الحدود الزمنية: أجريت هذه الدراسة خلال شهري شباط وآذار من العام } 2017 .
$$

الحدود البثـــرية: العاملين في مديريات التربية والتعليم في محافظة الخليل، والذين هم على رأس عملهم

$$
\text { حتى تاريخ (2017/1/31). }
$$

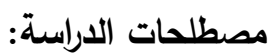

قام الباحث بتعريف المصطلحات الواردة في الدراسة وفقاً للتعريفات الواردة في المراجع العربية والأجنبية، وسيتم تعريف بعض المصطلحات وفقا لخبرات الباحث الذاتية، وفيما يلي تعريف لبعض مصطلحات الدرات الدراسة: الإدارة التحويلية (Transformational Leadership): عملية يسعى من خلالها القائد والمرؤوسون إلى أن لنعات ينهض كل منهما بالآخر للوصول إلى أعلى مستويات الدافعية والأخلاق. (Burns, 1978). مديرية التربية والتعليم: هي عبارة عن الجهة المسؤولة عن إدارة التعليم في المنطقة المتواجدة فيها، يرأسها مدير التوصي التربية والتعليم، وتضم عدد من الأقسام الإدارية والفنية. - - العاملين في مديريات التربية والتعليم: يعرفهم الباحث إجرائياً بأنهم الموظفين الذين يتولون العمل في أقسام

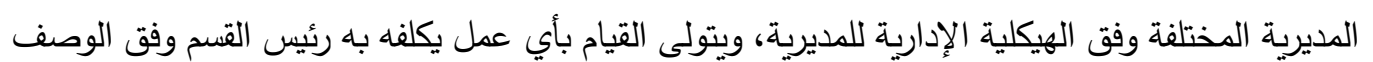
الوظيفي له. التميز القيادي: "القدرة على حث الأفراد لأن تكون لديهم الرغبة وملتزمين طوعياً في إنجاز الأهداف التظظيمية أو تجاوزها" (Musa \&Tulay, 2008, p.29). - - التميز البثري: يعرفه الباحث إجرائيا بأنهم العاملين الذين تتوفر فيهم عدد من الصفات التي تجهلهم لأن يكونوا بارزين ومميزين في جانب أو عدة جوانب. يعرئ.

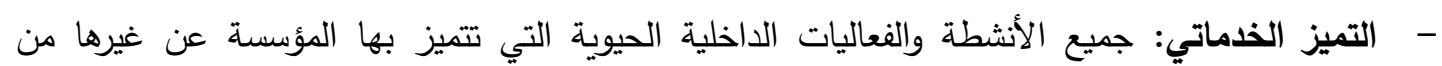
المؤسسات التي من خلالها يتم مقابلة احتياجات وتوقعات المتعاملين (إدري؛؛ والغالبي، 2009). متغيرات الاراسة: أولاً: المتغيرات الايموغرافية: الأية: 2 العمر، وله أربعة مستويات:(أقل من 30 عام، من 30-أقل من 40 مله عام، من 40- اقل من 50 عام، من 50 عام فأكثر). 3 4 سنوات الخدمة، ولها أربعة مستويات: (أقل من 5 سنوات، من 5-اقل من 10 سنوات، من 10 10 اقل من 15 سنة، من 15 سنة فأكثر). 5 المديرية، ولها ثلاثة مستويات: (شمال الخليل، وسط الخليل، جنوب الخليل، يطا). ثانياً: المتغير المستقل:" ممارسة الإدارة التحويلية في مديريات التربية والتعليم" ثالثاً: المتغير التابع:" تحقيق التميز المؤسسي في مديريات التربية والتعليم". 
الإطار النظري للاراسة والدراسات السابقة الإطار النظري لعل ما يشهده العصر من تغيير ملحوظ في مختلف مناحي الحياة، وما صاحب ذلك من ثورة معلوماتية وتكنولوجية

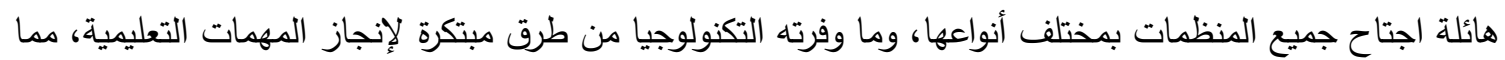
غير من شكل العملية التعليمية وهدفها وأوجد بيئة ذات تتافسية عالية دعت المنظمات إلى إيلاء عناية فائقة لطبيعة الجهود المبذولة لإنجاز الأعمال، للوصول إلى الفاعلية القصوى بالتركيز على ما يبذله المعلمين من جهود تتجاوز

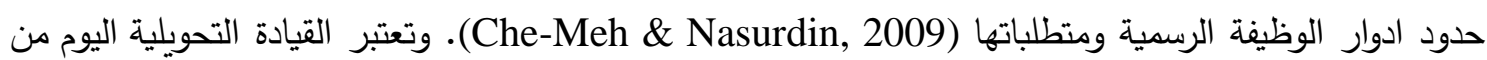

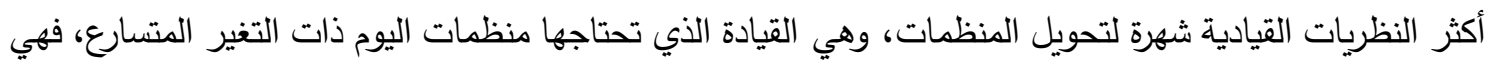
تقوم على إحداث تغييرات جذرية عن طريق إقناع المرؤوسين للنظر إلى ما هو أبعد من مصالحهم الذاتية من أجل

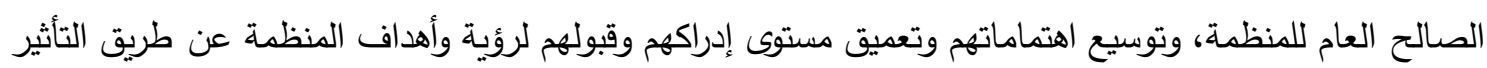

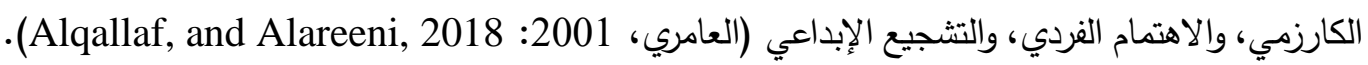
وتحرص المؤسسات المتميزة على ترجمة رؤيتها ورسالتها وغاياتها الإستراتيجية إلى واقع ملموس من أجل تحقيق

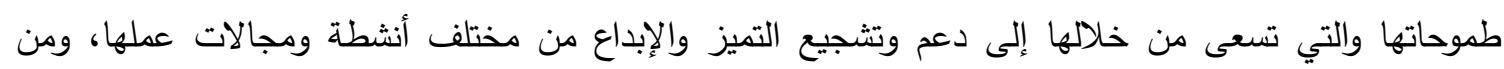
الضروري أن نؤكد في البداية أن الأداء التنظيمي المتميز لم يعد أحد الخيارات المطروحة أمام المنظمات، بل هل هو

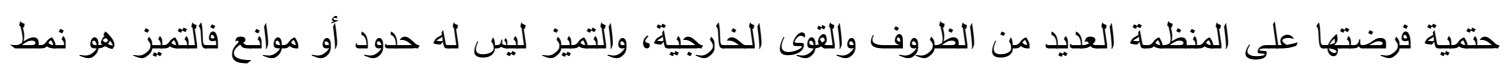

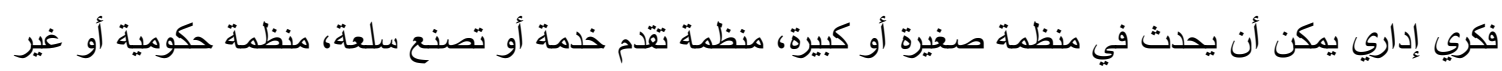

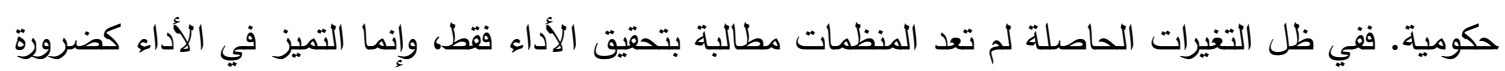

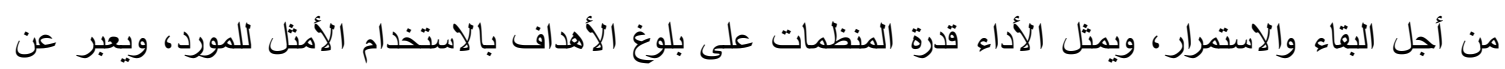

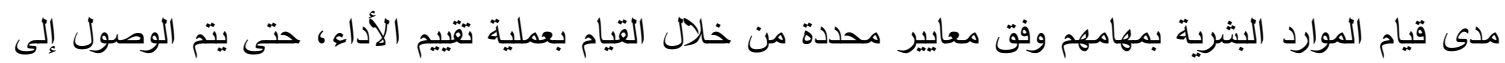
الأداء الأفضل والمتميز (غازي، 2014).

مفهوم الإدارة التحويلية: يعد مصطلح الإدارة التحويلية (Transformational Leadership) من المصطلحات التي ظهرت في مجال القيادة حديثًا، حيث ظهر هذا المصطلح لأول مرة في عام(1978م) بواسطة عالم التاريخ والسياسة الأمريكي جيمس ماجروجر

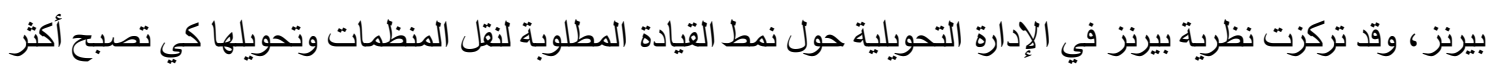

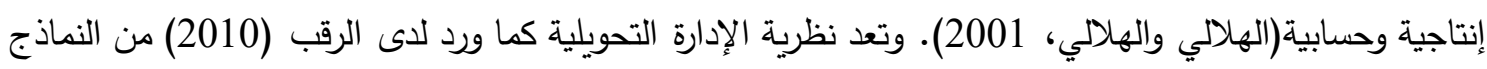

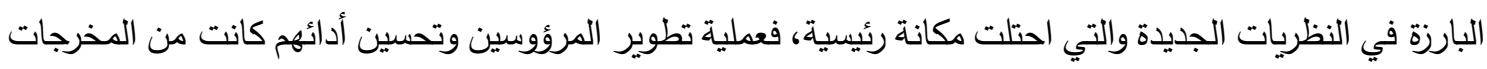
الأساسية لمثل هذه القيادة، فالمبدأ الأساسي لها يؤكد على تطوير المرؤوس وتحسين أدائه، فالقائد التحويلي يقدر الطاقة التهات

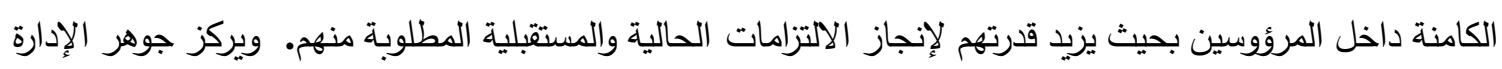

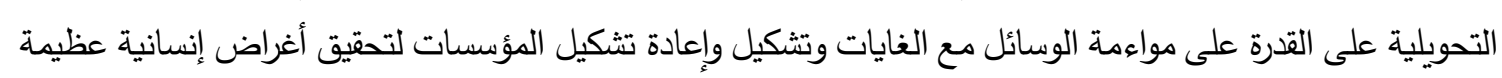

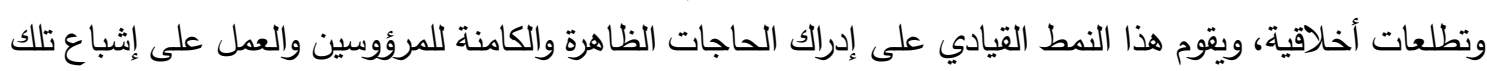
الحاجات واستثمار أقصى طاقات المرؤوسين بهدف تحقيق تغيير مقصود (الغامدي، 2000). كما وأن الإدارة التحويلية تعني مدى سعي القائد الإداري إلى الارتقاء بمستوى مرؤوسيه من أجل الإنجاز والتطوير الذاتي والعمل على تتمية

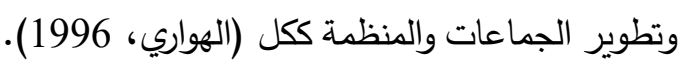


لغةً: ورد في لسان العرب " :حول، بتشديد الواو، أي تحويل الأمور ، وتحول عن الشيء : زال عنه إلى غيره وتحول من

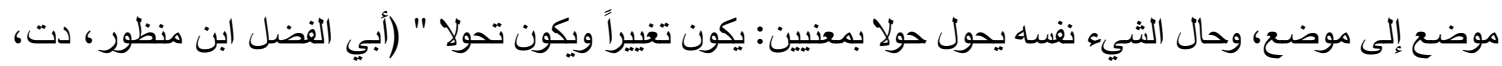
ص 225). اصطلاحاً: لا يوجد هناك تعريف متقق عليه من قبل التربويين والعلماء بسبب اختلاف وجهات النظر والفلسفات، ولكن هناك اتفاق واضح في مضمون المعني، وهنا نورد أهم هذه التعريفات: يعرفها (Bass \& Avolio, 1993) بأنها: "القيادة التي تتضمن عددا من المكونات ذات العلاقة المتبادلة من الكاريزما

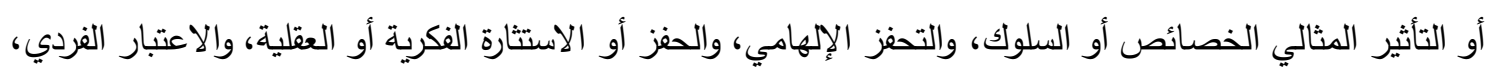

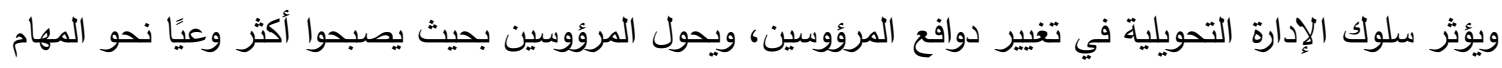

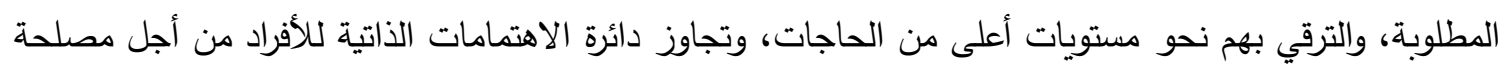

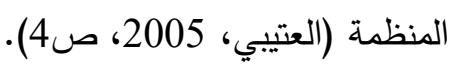

التميّز المؤسسي: ينطلق تعريف التميز المؤسسي من العديد من الكتب والدراسات والأبحاث، وهذا التعدد يعكس أهمية المفهوم التي جعلت المداخل الإدارية المعاصرة تركز جهودها لتحديد مفاهيم التميز التتظيمي، فمدخل الإدارة العلمية حدد مفهوم

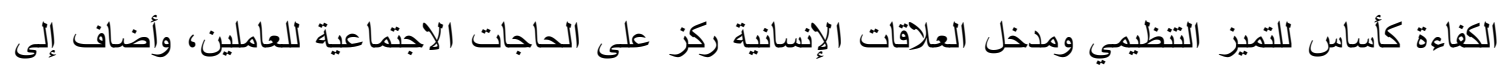
قاموس التميز التتظيمي مصطلحات مثل، العمل الجماعي، وفرق العمل، وجودة الحياة، والمناخ، والثقافة التتظيمية، وقد تواصلت الجهود الإدارية بما في ذلك المداخل الإدارية المعاصرة التي حددت مفهوم الفاعلية الذي يركز على وقلى ودئ تحقيق أهداف المنظمة الكلية في ظل التغيرات البيئية المتعددة، وتكمن أهمية التميز المؤسسي في (زايد، 2003) : 1. المنظمات بحاجة إلى وسائل وطرق للتعرف على العقبات التي تواجهها حال ظهورها.

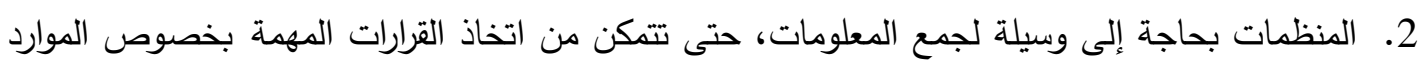

$$
\text { البشرية. }
$$

3. المنظمة بحاجة إلى تطوير أعضائها بصفة مستمرة سواء المديرين أو الموظفين، حتى يتمكنوا من المساعدة في جعل المنظمة أكثر تميزاً في الأداء. 4. المنظمة بحاجة إلى توفر المهارات اللازمة لصانع القرار سواء أكان فرداً أم جماعة؟ والتمعن في حساسية

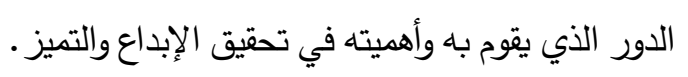

$$
\text { أنواع التميز المؤسسي: }
$$

1 التميز القيادي: للقيادة العليا تأثير مباشر على التميز، وذلك من خلال تتمية قدرات الأفراد، وتثجيعهم

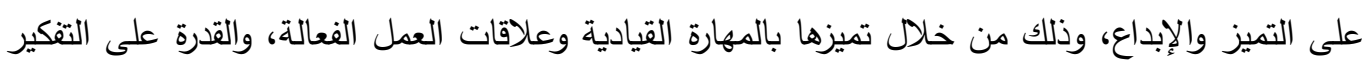
المتجدد الذي يبتعد عن التقليد، وكذلك اهتمامها بتثجيع المنافسة بين الأفراد للتوصل إلى التى أفكار جديدة. فالقائد المتميز هو الذي يستطيع رؤية كثير من المشكلات في الموقف الواحد، فهو يعي الأخطاء، ونواحي

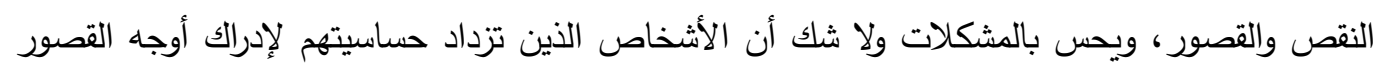

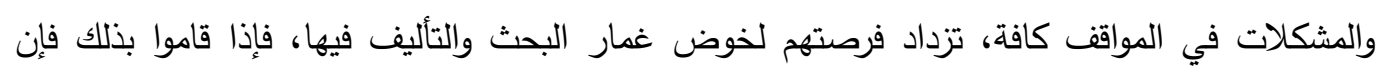
الاحتمال سيزداد أمامهم نحو التميز (Borghini , 2013). 2 التميز بتقديم الخدمة: إن فئات العاملين كافة يعدون بمثابة مستهلكين للسلع والخدمات، وعندما يتم الحصول

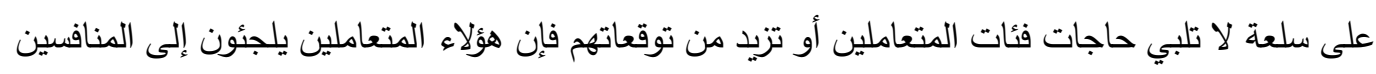


للتعامل معهم. وفي ظل إدارة التميز فإن اللجوء إلى هذه النتائج يعد مؤشراً على أن شيئاً ما يتم خطاً في أسلوب تقديم الخدمة التي أدت إلى إنتاج هذه الخدمة، وهذه الأعراض تفضي إلى خطة عمل لتصدي فئح هذه الأخطاء أو نواحي القصور (النعيمي؛ وآخرون، 2008). 3 التميز البشري: المنظمة هي تجمعات بشرية هادفة، والإدارة هي عملية تحقيق الأهداف التنظيمية بدرجة

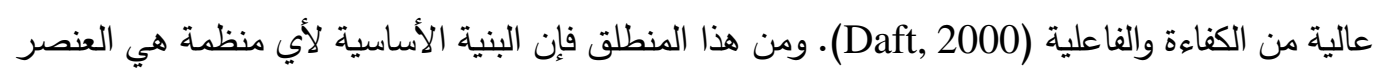

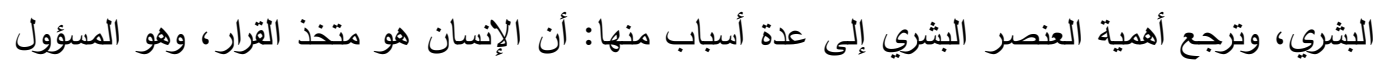

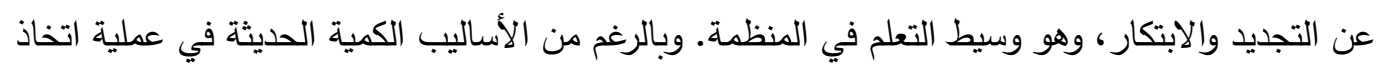
القرارات التظيمية إلا أن العنصر البشري هو العنصر الحاكم في عملية اتخاذ القرارات (غازي، 2014).

الاراسات السابقة:

أولاً: دراسات تتعلق بالإدارة التحويلية

- دراسة (Griffith, 2004) بعنوان "العلاقة بين الإدارة التحويلية ورضا المعلمين وأدائهم المدرسي ورغبتهم في ترك العمل". هدفت الدراسة إلى بيان العلاقة بين الإدارة التحويلية ورضا المعلمين وأدائهم المدرسي ورغبتهم في ترك العمل، وتم تطبيق هذه الدراسة على مدارس ابتدائية في منطقة تعليمية كبيرة بحشد الطلبة وخصائص المعلمين، وقد

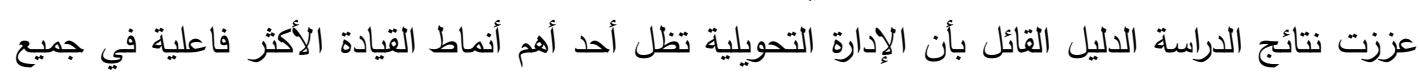

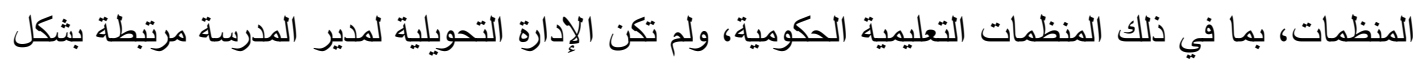
مباشر مع الأداء المدرسي وترك العمل، بل كان الرضا الوظيفي عاملاً وسيطاً بين هذين المتغيرين. وخرجت الدراسة بعدد من التوصيات.

دراسة الديب (2012) بعنوان "مدى ممارسة القيادات الإدارية الأكاديمية بالجامعات الفلسطينية للقيادة التحويلية وصعوباتها وسبل تنميتها".

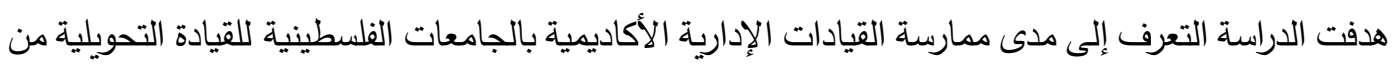
وجهة نظر أعضاء الهيئة التدريسية، ومعرفة الصعوبات التي تواجه هذه الممارسة ومعرفة أكثر السبل أهمية في بعض المقترحات التي قد تسهم في تفعيل هذه الممارسة، وذلك من خلال استخدام المنهج الوصفي التحليلي، وقد بلغ حجم عينة الدراسة (284) عضو هيئة تدريسية، وتم جمع البيانات عبر ثلاث استبيانات تمثلت الاستبانة

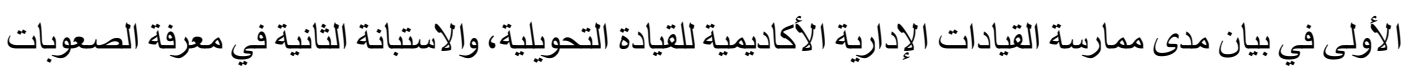

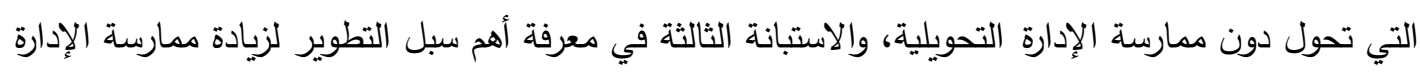

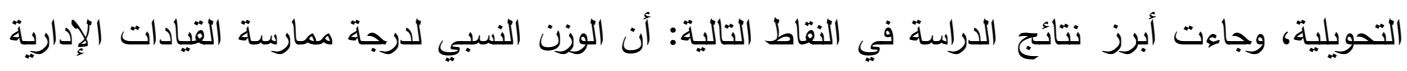

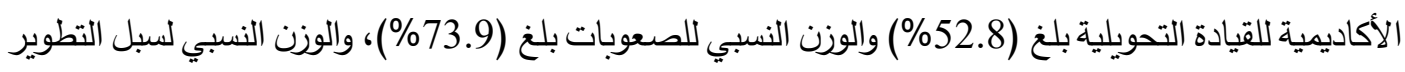

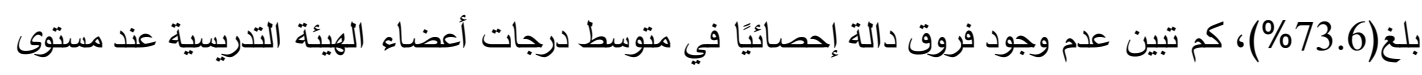

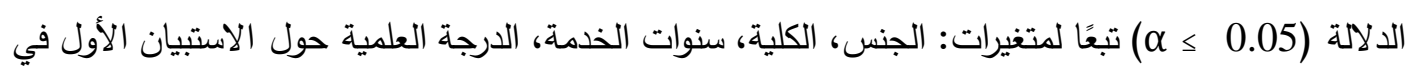

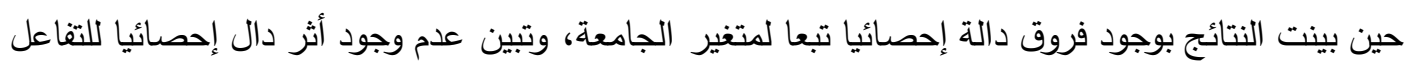

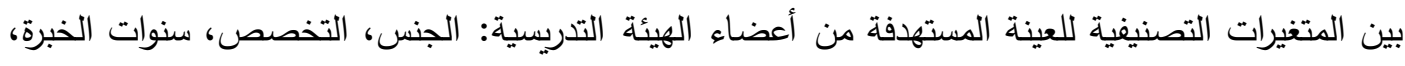

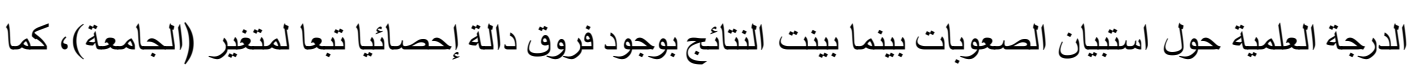
تبين عدم وجود أثر دال إحصائيا للتفاعل بين جميع المتغيرات التصنيفية للعينة المستهدفة من أعضاء الهيئة 
التدريسية: (الجنس، التخصص، الجامعة، سنوات الخبرة، الدرجة العلمية) حول استبيان سبل التطوير ـ وخرجت الأراسة بعدد من التوصيات.

-دراسة أبو هداف (2011) بعنوان "دور الإدارة التحويلية في تطوير فعالية المعلمين التدريسية بمدارس وكالة

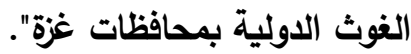
هدفت الدراسة إلى معرفة دور الإدارة التحويلية في تطوير فعالية المعلمين التدريسية بمدارس وكالة الغوث الدولية بمحافظات غزة. وتكونت عينة الدراسة من(412) معلما ومعلمة من معلمي المرحلة الإعدادية بمدارس وكالة الغوث الدولية، عبر استخدام استبيان مكون من (66) فقرة وزعت على (6) مجالات، وفق المنهج الوصفي

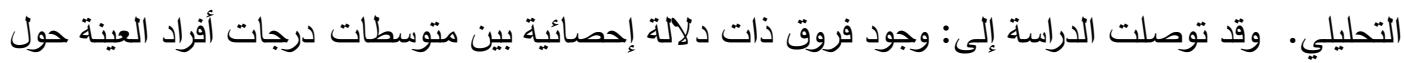
دور الإدارة التحويلية في تطوير فعالية المدرسين تعزى إلى متغير الجنس وكانت الفروق لصالح الإناث. كما تبين

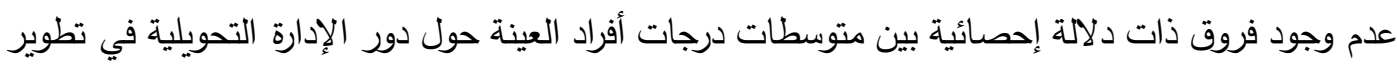

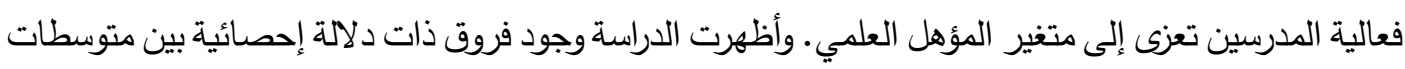
درجات أفراد العينة حول دور الإدارة التحويلية في تطوير فعالية المدرسين تعزى إلى متغير سنوات الخئ الخبرة وكانت

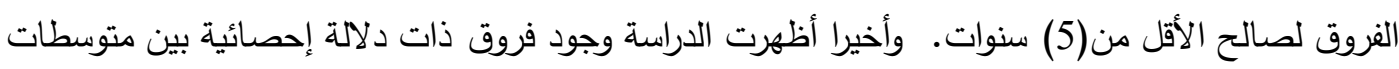
درجات أفراد العينة حول دور الإدارة التحويلية في تطوير فعالية المدرسين تعزى إلى متغير المحافظة وكانت

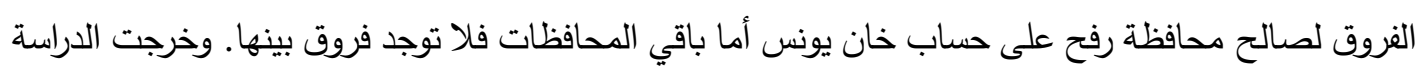
بعدد من التوصيات. ثانيا: دراسات تتعلق بالتميز المؤسسي: دراسة حسن. (2010) بعنوان "ممارسات إدارة الموارد البشرية وأثرها في تحقيق التميز المؤسسيكئدراسة

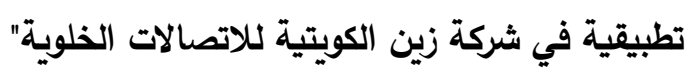
هدفت الدراسة التعرف إلى أثر ممارسات إدارة الموارد البشرية في تحقيق التميز المؤسسي في شركة زين الكويتية

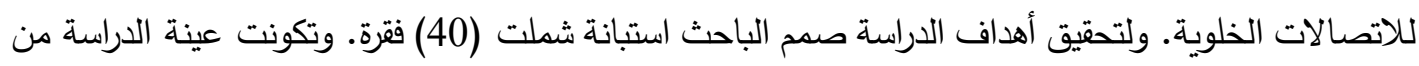
(253) مغردة. توصلت الدراسة إلى عدد من النتائج أبرزها: (وجود أثر ذي دلالة معنوية للاستقطاب والتعيين في تحقيق التميز القيادي والتميز بتقديم الخدمة، وجود أثر ذي دلالة معنوية للتدريب والتطوير في تحقيق التحديق التميز القيادي والتميز بتقديم الخدمة، وجود أثر ذي دلالة معنوية لتقييم الأداء في تحقيق التميز القيادي والتميز بتقديم

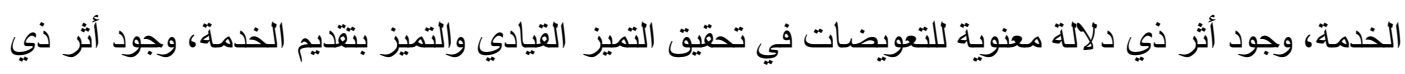

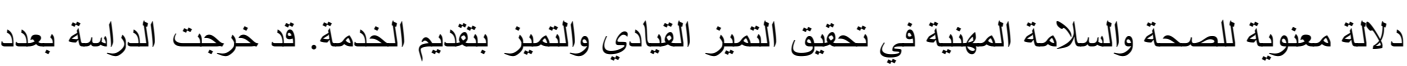
من التوصيات. دراسة البحيصي. (2014) بعنوان "دور تمكين العاملين في تحقيق التميز المؤسسي-دراسة ميدانية على في

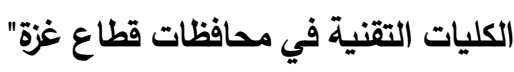
هدفت الدراسة إلى التعرف على دور تمكين العاملين في تحقيق التميز المؤسسي في الكليات التتنية في قطاع غزة،

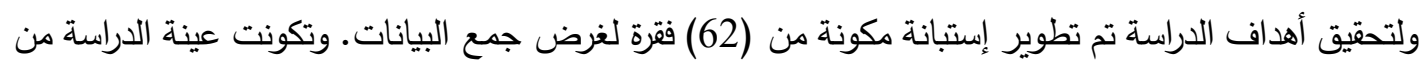
(205) فرداً من موظفي الكليات التقنية في قطاع غزة، وشملت العينة الموظفين الإداريين والأكاديميين في تلك

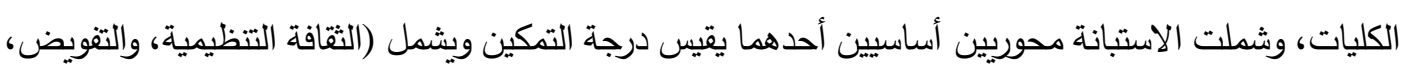
والمشاركة بالمعلومات، وفرق العمل، والآخر يقيس درجة التميز المؤسسي ويشمل (التميز القيادي، والتميز 
البشري، والتميز الخدماتي)، وقام الباحث باستخدام العينة العشوائية الطبقية. وقد توصلت الدراسة إلى مجموعة

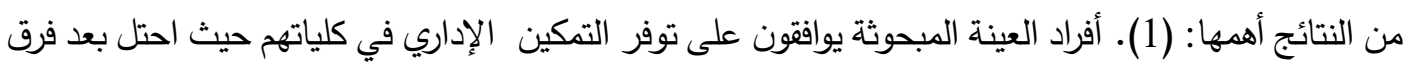
العمل المرتبة الأولى، تلاه بعد تفويض السلطة، والمشاركة بالمعلومات، وبعد الثقافة التظيمية في المرتبة الأخيرة

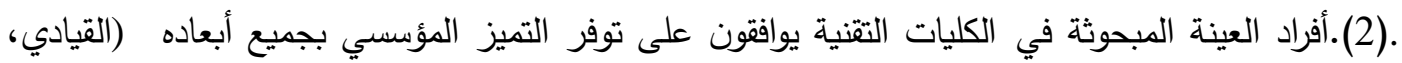

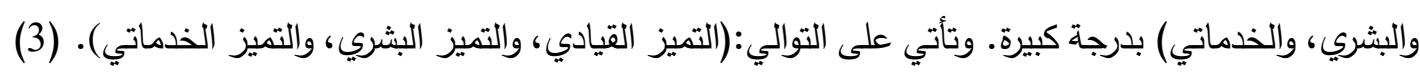

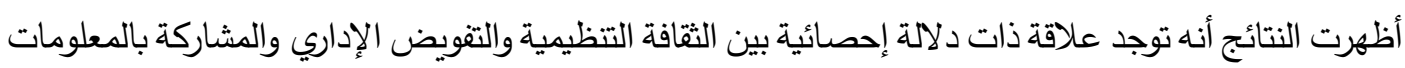

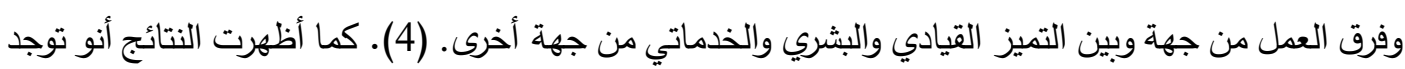

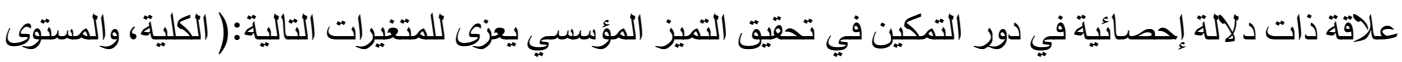
التعميمي، وسنوات الخدمة، والعمر ). (5). كما أثارت النتائج إلى وجود علاقة ذات دلالة إحصائية بين التمكين

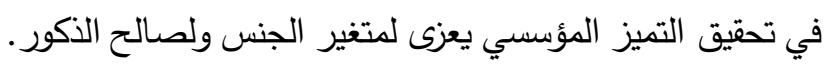
- - دراسة (Hatian \& Irawan, 2015) بعنوان " قياس الأداء الكلي باستخدام بطاقة الأداء المتوازن في بنك جابر بانتن في أندونيسيا" هدفت الدراسة إلى قياس الأداء الكلي باستخدام بطاقة الأداء المتوازن والتي لديها أربعة أبعاد لقياس أداء بنك

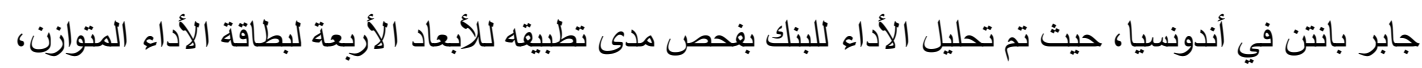

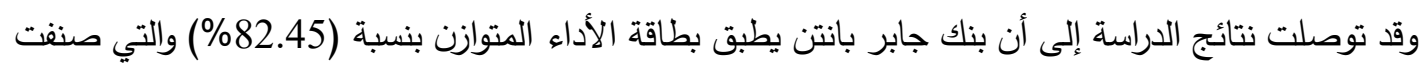
كنسبة أداء جيدة. تعقيب على الدراسات السابقة:

بعد الاستعراض السابق للدراسات السابقة العربية والأجنبية توصل الباحث إلى أن موضوع الإدارة التحويلية

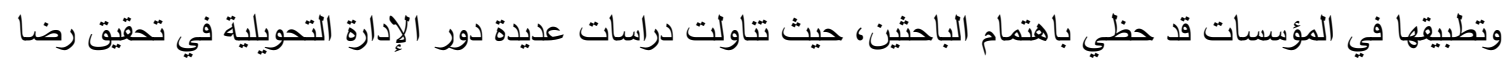

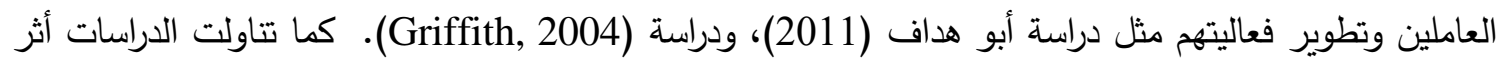
متغيرات عدة في تحقيق التميز المؤسسي مثل دراسة حسن (2011). وتتاولت دراسات أخرى مدى استخدام بطاقة

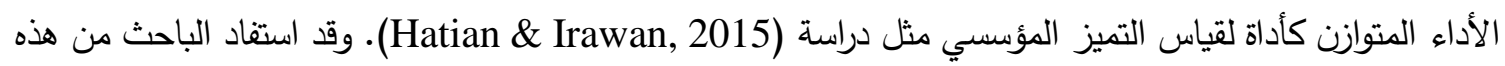

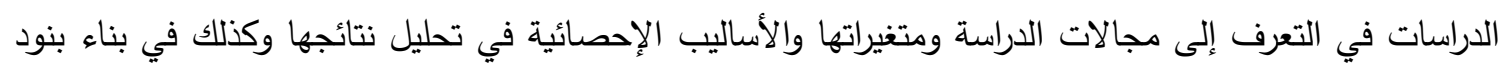

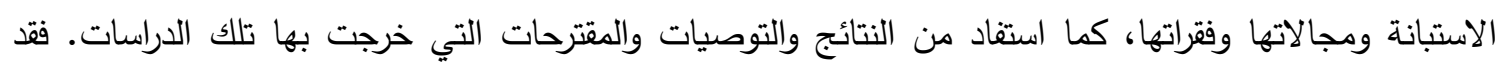

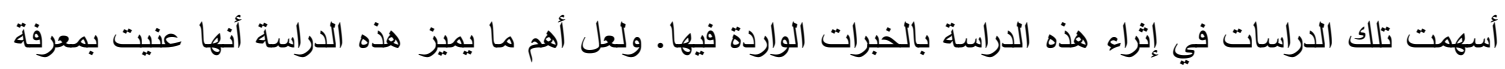
درجة ممارسة الإدارة التحويلية من وجهة نظر العاملين في مديريات التربية والتعليم، وكذلك معرفة درجة التميز

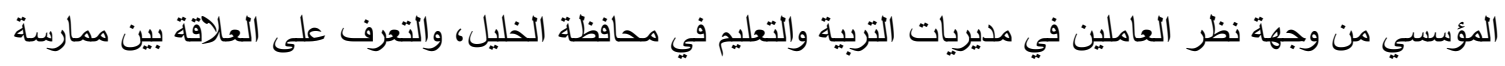

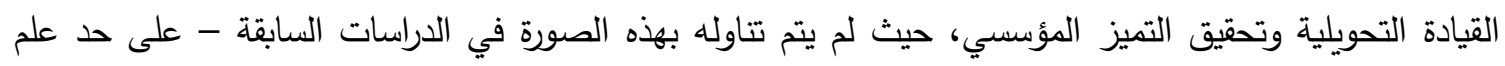

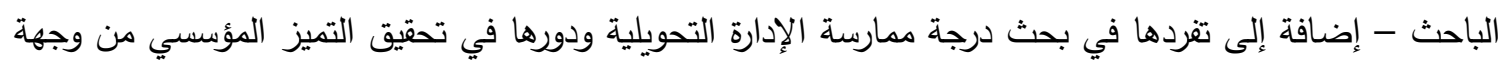
نظر العاملين في مديريات التربية والتعليم في محافظة الخليل. الإطار العملي للاراسة منهج الاراسة: أجريت هذه الدراسة ما بين شهري شباط وآذار من العام 2017، واستخدم الباحث في إنجازها المنهج الوصفي التحليلي. 
مجتمع الاراسة:

تكون مجتمع الدراسة من جميع العاملين في مديريات التربية والتعليم في محافظة الخليل والذين هم على رأس عملهح

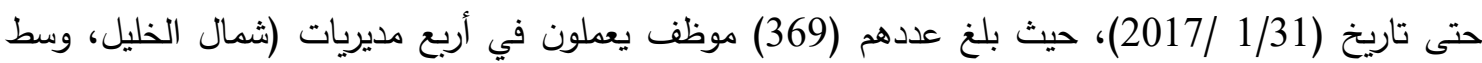
الخليل، جنوب الخليل، يطا).

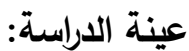

قام الباحث بتوزيع الاستبانة على عينة عشوائية من المديريات الأربعة، وقد بلغ عدد الاستبانات المستردة (103) استبانات بنسبة (27.9\%) من حجم المجتمع، وهي عينة ممثلة إحصائياً.

أداة الدراسة: قام الباحث بالاستعانة باستبانة الديب (2012) لقياس مدى ممارسة القيادات الإدارية الأكاديمية بالجامعات الفلسطينية للقيادة التحويلية وصعوباتها وسبل تتميتها، لقياس درجة ممارسة الإدارة التحويلية من وجهة نظر العاملين في مديريات التربية والتعليم في محافظة الخليل، كما قام الباحث بإعداد استبانة لقياس درجة التميز المؤسسي من وجهة العاملين في مديربات التربية والتعليم، وقد تكونت الاستبانة بمجملها من ثلاثة أقسام:

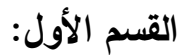
ويحتوي هذا الجزء على البيانات الأولية عن العاملين في مديريات التربية والتعليم في محافظة الخليل والذين يقومون بتعبئة الاستبانة وهي: (الجنس، المؤهل العلمي، العمر ، سنوات الخدمة، والمديرية).

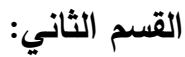
ويقيس درجة ممارسة الإدارة التحويلية من وجهة نظر العاملين في مديريات التربية والتعليم في محافظة

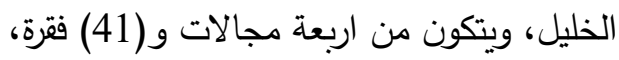

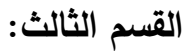

ويقيس درجة التميز المؤسسي من وجهة نظر العاملين في مديريات التربية والتعليم في محافظة الخليل،

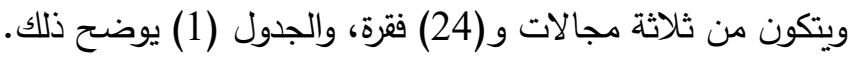
جدول (1): محاور الدراسة الرئيسية

\begin{tabular}{|c|c|c|}
\hline \multicolumn{3}{|c|}{ محاور الدراسة الرئيسية لارجة ممارسة الإدارة التحويلية } \\
\hline عدد الفقرات & 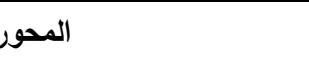 & الرقم \\
\hline 11 & 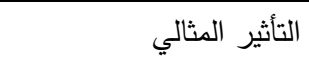 & 1 \\
\hline 10 & الحفز الإلهامي & 2 \\
\hline 10 & استثارة التنكير & 3 \\
\hline 10 & الاهتمام بالفرد & 4 \\
\hline 41 & 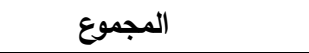 & \\
\hline \multicolumn{3}{|c|}{ محاور الاراسة الرئيسية لدرجة التميز المؤسسي } \\
\hline 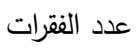 & الدحور & الرقم \\
\hline 9 & التميز القيادي & 1 \\
\hline 9 & التميز البشري & 2 \\
\hline 6 & التميز في تقديم الخدمة & 3 \\
\hline 24 & 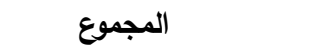 & \\
\hline
\end{tabular}


صدق الأداة:

يعبر صدق الأداة عن مدى صلاحية الأداة المستخدمة لقياس ما وضعت لقياسه، وقد قام الباحث بعرض الاستنبانة على عدد من المحكمين والمختصين في الميدان التربوي والإداري، وعدد من ذوي الخبرة في الجامعات الفلسطينية، وقد تم تعديل فقرات الاستبانة وفق الملاحظات والتعديلات المقترحة، وأعيد صياغة الاستبانة بشكلها النهائي وفقاً

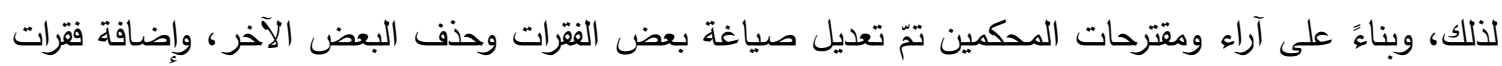

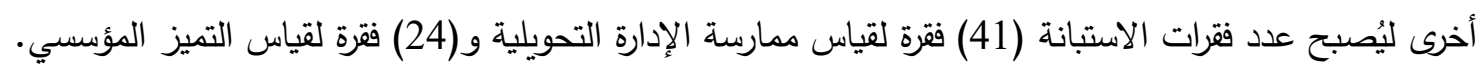

ثبات الأداة: للتحقق من ثبات أداة القياس تم فحص الاتساق الداخلي والثبات لفقرات الاستبانة بحساب معامل كرونباخ ألفا

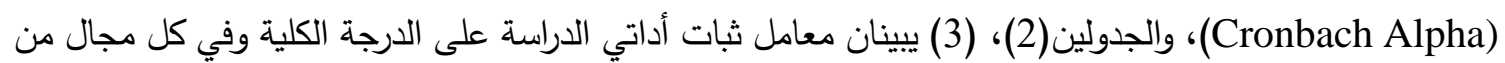
مجالات الدراسة. جدول (2): مصفوفة معاملات الثبات لأبعاد الدراسة الخاصة بمجالات ممارسة الإدارة التحولية حسب كرونباخ ألفا

\begin{tabular}{|c|c|c|}
\hline قيمة ألفا & عدد الفقرات & مجالات الدراسة \\
\hline 0.877 & 11 & التأثير المثالي \\
\hline 0.912 & 10 & الحفز الإلهامي \\
\hline 0.911 & 10 & استثارة التفكير \\
\hline 0.921 & 10 & الاهتمام بالفرد \\
\hline 0.967 & 41 & الارجة الكلية \\
\hline
\end{tabular}

بالنظر إلى جدول (2) يتضح أن قيمة الفا تراوحت بين (0.877) و(0.921)، في حين بلغت قيمة الفا على الارجة الكلية (0.967)، مما يشير إلى دقة أداة القياس.

جدول (3): مصفوفة معاملات الثبات لأبعاد الدراسة الخاصة بمجالات التميز المؤسسي حسب كرونباخ ألفا.

\begin{tabular}{|c|c|c|}
\hline قيمة ألفا & عدد الفقرات & مجالات الدراسة \\
\hline 0.927 & 9 & التميز القيادي \\
\hline 0.928 & 9 & التميز البشري \\
\hline 0.905 & 6 & التميز في تقديم الخدمة \\
\hline 0.967 & 24 & الارجة الكلية \\
\hline
\end{tabular}

بالنظر إلى جدول (3) يتضح أن قيمة ألفا تراوحت بين (0.905) و(0.928)، في حين بلغت قيمة ألفا على الدرجة الكلية (0.967)، مما يثير إلى دقة أداة القياس.

إجراءات الاراسة: بعد التأكد من صدق وثبات أداة الدراسة، وتحديد العينة، قام الباحث بمراجعة المسؤولين في وزارة التربية والتعليم العالي الفلسطينية، حيث تمت الموافقة على إجراء مثل هذه الدراسة، والسماح بتوزيع الاستبانة على العاملين في مديريات

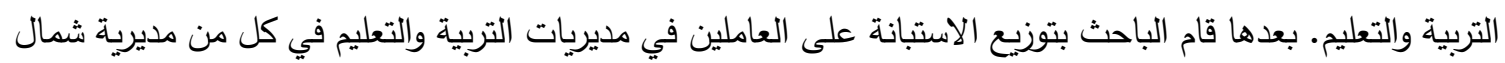
الخليل، ومديرية الخليل، ومديرية جنوب الخليل، ومديرية يطا، حيث تم توزيع (200) استبانة. 
المعالجة الإحصائية:

بعد جمع بيانات الدراسة قام الباحث بمراجعتها وذلك تمهيدا لإدخالها للحاسب وقد تم إدخالها للحاسب وذلك بإعطائها أرقاما معينة، أي بتحويل الإجابات اللفظية إلى رقمية حيث أعطيت الإجابة بدرجة كبيرة جداً خمس درجات، والإجابة لإباتية بدرجة كبيرة أربع درجات، والإجابة بدرجة متوسطة ثلاث درجات، والإجابة بدرجة قليلة درجتين، والإجابة بدرجة قليلة

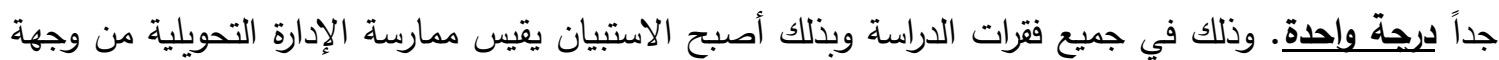
نظر العاملين في مديريات التربية والتعليم في محافظة الخليل ودورها في تحقيق التميز المؤسسي بالاتجاه الموجب. وقد تمت المعالجة الإحصائية للبيانات باستخراج الأعداد، المتوسطات الحسابية والانحرافات المعيارية واختبار (ت) وتحليل التباين الأحادي One Way ANOVA ومعادلة الثبات كرونباخ الفا وذلك باستخدام برنامج الرزم الاحصائية

للعلوم الاجتماعية (SPSS). نتائج الاراسة ومناقثتها وتفسيرها والتوصيات: يتتاول هذا المبحث عرضاً للنتائج التي توصل إليها الباحث من خلال استجابة ألتوريات أفراد عينة الدراسة حول درجة ممارسة الإدارة التحويلية ودورها في تحقيق التميز المؤسسي من وجهة نظر العاملين في مديريات التربية والتعليم في محافظة الخليل، وفقاً لتساؤلات الدراسة وفرضياتها، ويمكن تفسير قيمة المتوسط الحسابي(المرجع) للعبارات في أداة الدراسة (الاستبانة) كما يلي:

\begin{tabular}{|c|c|}
\hline & : دلالة المتوسط \\
\hline الدلائة & المتوسط الحسابي \\
\hline منخفض جداً & $1.80-1.00$ \\
\hline منخفض & $2.61-1.81$ \\
\hline متوسط & $3.42-2.62$ \\
\hline مرتفع & $4.23-3.43$ \\
\hline مرتفع جداً & $5.00-4.24$ \\
\hline
\end{tabular}

وفي ضوء معالجة بيانات الدراسة إحصائيا توصل الباحث للنتائج الآتية: الإجابة عن السؤال الأول: ما درجة ممارسة الإدارة التحويلية من وجهة نظر العاملين في مديريات التربية والتعليم

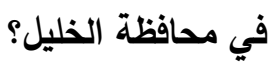
جدول (5): المتوسطات الحسابئة والانحرافات المعيارية لدرجة ممارسة الإدارة التحولية في مديريات التربية والتعليم

\begin{tabular}{|c|c|c|c|}
\hline الارجة & الانحراف المعياري & المتوسط الحسابي & مجالات الدراسة \\
\hline متوسط & 0.707 & 3.05 & التأثير المثالي \\
\hline متوسط & 0.758 & 3.15 & الحفز الإلهامي \\
\hline متوسط & 0.767 & 3.37 & استثارة التنكير \\
\hline متوسط & 0.794 & 3.03 & الاهتمام بالفرد \\
\hline متوسط & 0.679 & 3.15 & الدرجة الكلية \\
\hline
\end{tabular}

يلاحظ من خلال النظر إلى الجدول (5) ومن خلال استجابة أفراد عينة الدراسة، أن درجة ممارسة الإدارة التحويلية من وجهة نظر العاملين في مديريات التربية والتعليم كانت متوسطة، على الدرجة الكلية بمتوسط حسابي (3.15)

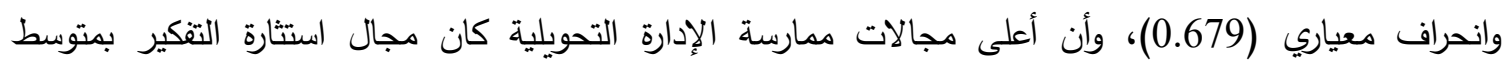


حسابي(3.37) وانحراف معياري (0.767)، تلاه مجال الحفز الإلهامي بمتوسط حسابي (3.15) وانحراف معياري (0.758)، تلاه التأثير المثالي بمتوسط حسابي (3.05) وانحراف معياري (0.707)، وأخيراً الاهتمام الفردي بمتوسط الفيط حسابي (3.03) وانحراف معياري (0.794)، ويعزو الباحث السبب في تلك النتائج إلى بروز الأنماط القيادية التحويلية في المؤسسات العامة، وعدم الرغبة في تفويض الصلاحيات من قبل المدراء بسبب المركزية الزائدة في العمل. جدول (6): المتوسطات الحسابية والانحرافات المعيارية لفقرات ممارسة الإدارة التحويلية في مديريات التربية والتعليم الإنية

\begin{tabular}{|c|c|c|c|}
\hline 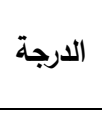 & الانعراف & الحسابي & 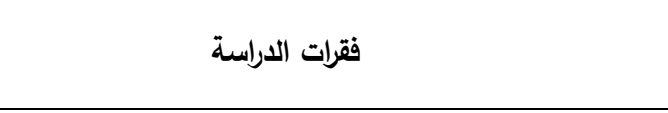 \\
\hline 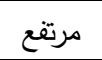 & 0.871 & 3.81 & يهتم بإعطاء الحوافز للقيام بالتغيير . \\
\hline 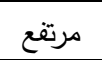 & 0.878 & 3.60 & يعطينا معنى للعمل من خلال تحفيزه وتشجيعه لنا. \\
\hline 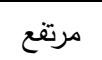 & 0.921 & 3.60 & يراعي الفروق الفردية بيننا في مجال الاحتياجات والرغبات. \\
\hline 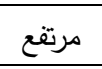 & 0.987 & 3.54 & يحافظ على التواصل والاتصال معنا باختلاف آرائنا وانتماء اتنا. \\
\hline مرتفع & 1.01 & 3.51 & يتصدى للمصاعب التي تواجه تطور العمل بشجاعة. \\
\hline 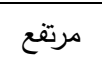 & 1.00 & 3.51 & يعطينا الوقت الكافي للاستماع لأفكارنا. \\
\hline 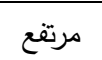 & 1.00 & 3.51 & يعمل على استثارة التفكير لحل المشكلات. \\
\hline متوسط & 0.955 & 3.41 & يعتمد على النقد البناء عند الإخفاق في حل المشكلات. \\
\hline متوسط & 1.01 & 3.41 & يسمح بقدر كبير من المخاطرة المحسوبة في اتخاذ القرارات. \\
\hline متوسط & 0.932 & 3.39 & يعمل على جعل أفراد الفريق يشعرون بالانتماء له ولأفكاره. \\
\hline متوسط & 0.932 & 3.39 & نشعر بصدق أقواله من خلال أفعاله. . \\
\hline متوسط & 0.993 & 3.39 & يسمح بتداول الأفكار المتعارضة للوصول إلى الطريقة المثلى. \\
\hline متوسط & 1.00 & 3.38 & يثجع على استخدام أساليب جديدة للعمل. . \\
\hline متوسط & 1.09 & 3.35 & يشارك الجميع في عملية التغيير. \\
\hline متوسط & 1.01 & 3.32 & يتجدد في أفكاره ويطمح إلى التغيير. \\
\hline متوسط & 1.01 & 3.32 & تتسجم أقواله مع أفعاله. \\
\hline متوسط & 1.07 & 3.29 & يفوض الصلاحيات للعاملين. ي \\
\hline متوسط & 1.03 & 3.27 & يبرر التغييرات المرغوب فيها بأسلوب منطقي. \\
\hline متوسط & 1.01 & 3.25 & ينجز مهامه بمشاركة العاملين معه. \\
\hline 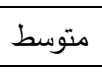 & 1.01 & 3.21 & يعتمد على أسلوب النقد البناء والتعزيز بكل أمر أقوم بانجازه \\
\hline متوسط & 0.990 & 3.19 & يثاركنا في مواجهة المخاطر. \\
\hline متوسط & 1.12 & 3.19 & يعتمد أسلوبه في العمل على استثارة روح الإبداع والابتكار فينا. \\
\hline 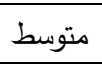 & 1.05 & 3.17 & يزرع فينا الإحساس بأهداف المؤسسة والوزارة وغاياتها. \\
\hline متوسط & 0.953 & 3.14 & يقوم بيناء فريق العمل لامتلاكه المهارات الإنسانية. \\
\hline متوسط & 1.04 & 3.14 & يراعي مشاعر العاملين معه باختلافاتهم. \\
\hline متوسط & 1.04 & 3.14 & يعتمد على الأساليب الإدارية الحديثة في إدارة القسم. \\
\hline متوسط & 1.07 & 3.12 & يقدم احتياجاتنا على احتياجاته في مواقف عدة. \\
\hline متوسط & 1.11 & 3.11 & يصغي باهتمام لكل حديث يوجه له. \\
\hline متوسط & 1.11 & 3.11 & ينسج معنا علاقات حميمة مما يعزز النسيج الاجتماعي. \\
\hline متوسط & 0.978 & 3.05 & سلوكه معنا يرفع معنوياتتا وتقدم عملنا. \\
\hline متوسط & 1.06 & 2.95 & يدفعنا نحو استخدام تقنية المعلومات كونها أسرعطرق التعلم. \\
\hline متوسط & 1.11 & 2.88 & يعمل على استثارتتا نحو التغيير. \\
\hline
\end{tabular}




\begin{tabular}{|c|c|c|c|}
\hline 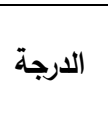 & الانحراف المعياري & الحستوسطي & 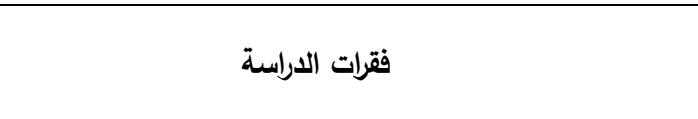 \\
\hline متوسط & 1.08 & 2.72 & اهتمامه باحتياجاتنا الثخصية في أعلى سلم أولوياته. \\
\hline متوسط & 1.08 & 2.72 & يقوم أداء العاملين معه كونه يمتلك المهارات الفنية لذلك. \\
\hline متوسط & 1.15 & 2.68 & يتخذ القرارات المهمة بحذر. \\
\hline متوسط & 1.15 & 2.68 & ينأى بنفسه عن تحقيق مكاسب شخصية. \\
\hline متوسط & 1.19 & 2.67 & ينال إعجابنا به في كل عمل يقوم به. \\
\hline منخفض & 0.983 & 2.60 & يباشر عملية تفويض العمل، للاطمئنان على سير العمل ونجاحه. \\
\hline منخفض & 0.983 & 2.60 & يثق بالجميع بقدر كبير. \\
\hline منخفض & 1.15 & 2.42 & يثير فينا التحدي والثبات. \\
\hline 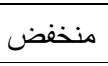 & 1.10 & 2.26 & تعامله الحسن معنا يفرض علينا احترامه. \\
\hline
\end{tabular}

بالنظر إلى جدول (6)، يتبين أن أعلى الفقرات في مجال ممارسة الإدارة التحويلية كانت:

يهتم بإعطاء الحوافز للقيام بالتغيير ، بمتوسط حسابي (3.81) وانحراف معياري (0.871).

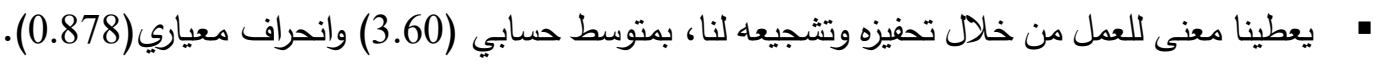
يراعي الفروق الفردية بينتا في مجال الاحتياجات والرغبات، بمتوســط حســابي (3.60) وانحراف معياري

يحافظ على التواصل والاتصـال معنا باختلاف آرائنا وانتماءاتتا، بمتوسط حسابي (3.54) وانحراف معياري

• يتصدى للمصاعب التي تواجه تطور العمل بشجاعة، بمتوسط حسابي (3.51) وانحراف معياري (1.01). • يعطينا الوقت الكافي للاستماع لأفكارنا، بمتوسط حسابي (3.51) وانحراف معياري (1.00).

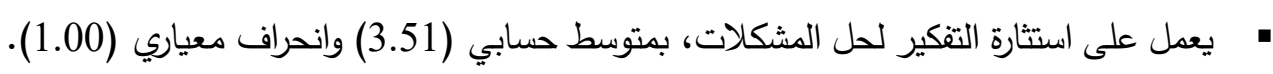
في كانت أدنى الفقرات في مجال ممارسة الإدارة التحويلية: • تعامله الحسن معنا يفرض علينا احترامه، بمتوسط حسابي (2.26) وانحراف معياري(1.10). يثير فينا التحدي والثبات، بمتوسط حسابي (2.42) وانحراف معياري (1.15). هئ بالجميع بقدر كبير ، بمتوسط حسابي (2.60) وانحراف معياري (0.983). باشر عملية تفويض العمل، للاطمئنان على سير العمل ونجاحه، بمتوسط حسابي (2.60) وانحراف معياري

الإجابة عن السؤال الثاني: ما درجة التميز المؤسسي من وجهة نظر العاملين في مديريات التربية والتعليم في

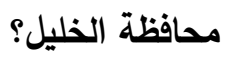

جدول (7): المتوسطات الحسابية والانحرافات المعيارية لدرجة التميز المؤسسي في مديريات التربية والتعليم

\begin{tabular}{|c|c|c|c|}
\hline الارجة & الانحراف المعياري & المتوسط الحسابي & مجالات الدراسة \\
\hline متوسط & 0.780 & 3.25 & التميز القيادي \\
\hline متوسط & 0.896 & 2.86 & التميز البشري \\
\hline متوسط & 0.886 & 3.10 & التميز في تقديم الخدمة \\
\hline متوسط & 0.798 & 3.07 & الدرجة الكلية \\
\hline
\end{tabular}


بالنظر إلى جدول (7) يتبين أن درجة التميز المؤسسي في مديريات التربية والتعليم كانت متوسطة على الدرجة الكلية بمتوسط حسابي (3.07) وانحراف معياري (0.798)، وأن أعلى مجالات التميز كانت التميز القيادي بمتوسط حسابي (3.25) وانحراف معياري (0.780) تلاه التميز في تقديم الخدمة بمتوسط حسابي (3.10) وانحراف معياري (0.886)، وأخيراً التميز البشري بمتوسط حسابي (2.86) وانحراف معياري (0.896)، ويعزو الباحث السبب في تلك النتائج إلى فئل

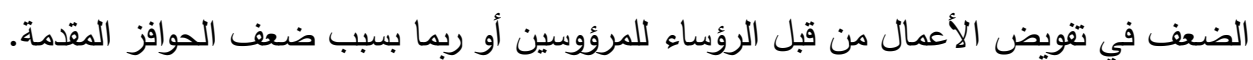
جدول (8): المتوسطات الحسابية والانحرافات المعيارية لفقرات درجة التميز المؤسسي في مديريات التربية والتعليم

\begin{tabular}{|c|c|c|c|}
\hline 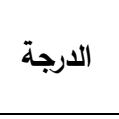 & الانحراف & المتوسط & 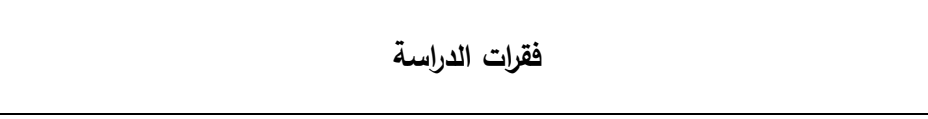 \\
\hline 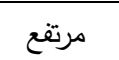 & 0.883 & 3.53 & تسعى إدارة المؤسسة باستمرار إلى التميز في تقديم الخدمة للجمهور \\
\hline متوسط & 1.07 & 3.40 & تعتمد المؤسسة الوسائل التكنولوجية الحديثة في تقديم خدماتها \\
\hline متوسط & 0.940 & 3.37 & تتولى إدارة المؤسسة عملية التخطيط للاحتياجات المستقبلية \\
\hline متوسط & 1.01 & 3.33 & تثجع إدارة المؤسسة الموظفين نحو تقديم أفكار متميزة \\
\hline متوسط & 0.898 & 3.32 & تتبنى إدارة المؤسسة الأهداف الإستراتيجية وفقا لاحتياجات المتعاملين \\
\hline متوسط & 0.967 & 3.25 & تتبنى إدارة المؤسسة الأهداف الإستراتيجية وفقا لاحتياجات العاملين فيها \\
\hline متوسط & 1.12 & 3.23 & توفر المؤسسة لموظفيها أدوات حديثة تساعدهم على القيام بأعمالهم بجودة عالية \\
\hline متوسط & 1.07 & 3.23 & تتسم إجراءات تقديم الخدمة بالسرعة والراحة \\
\hline متوسط & 0.989 & 3.22 & تؤكد إدارة المؤسسة الالتزام بمضامين التميز المؤسسي \\
\hline متوسط & 1.02 & 3.22 & تقوم المؤسسة بالرقابة وبشكل مستمر على مرافقها لتحسين آليات تقديم الخدمة \\
\hline متوسط & 1.00 & 3.13 & 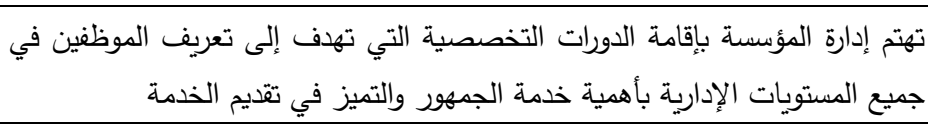 \\
\hline متوسط & 1.02 & 3.10 & تسعى إدارة المؤسسة إلى تبني فلسفة التغيير حسب الحاجة \\
\hline متوسط & 1.08 & 3.06 & تقوم المؤسسة بتطوير كفاءات موظفيها لتحقيق التميز والإبداع \\
\hline متوسط & 1.06 & 3.00 & تعمل أدارة المؤسسة على تحفيز الموظفين لتتمكن من تقديم خدمات متميزة \\
\hline متوسط & 0.954 & 3.00 & تقوم المؤسسة بالتأكد من حسن استثمارها للعاملين \\
\hline متوسط & 1.08 & 3.00 & تشجع المؤسسة التغذية الراجعة من الموظفين للارتقاء بمستوى الخدمات \\
\hline متوسط & 1.07 & 2.99 & تخضع عمليات تقديم الخدمة إلى عمليات ضبط وتحسين مستمرين \\
\hline متوسط & 1.17 & 2.95 & تستخدم المؤسسة برامج فعالة لدمج الموظفين الجدد في العمل \\
\hline متوسط & 1.12 & 2.92 & تستقطب المؤسسة ذوي الكفاءات للعمل فيها \\
\hline متوسط & 1.21 & 2.86 & تخصص المؤسسة موازنة خاصة للعاملين بتنفيذ الأنشطة الاجتماعية. \\
\hline متوسط & 1.11 & 2.79 & تهتم المؤسسة بقياس الرضا الوظيفي لموظفيها بشكل دوري \\
\hline متوسط & 1.12 & 2.78 & تقوم المؤسسة بإجراء استطلاعات مستمرة للتعرف على احتياجات المتعاملين معها \\
\hline 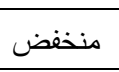 & 1.17 & 2.52 & تتيح المؤسسة فرص ابتعاث الموظفين المتميزين لديها \\
\hline منخفض & 1.13 & 2.36 & يحصل الموظفون على مكافآت تتاسب تقييمهح \\
\hline
\end{tabular}

بالنظر إلى جدول (8) يتبين أن الفقرة التي جاءت مرتفعة في مجال التميز المؤسسي الفقرة التي تتص على" تسعى إدارة المؤسسة باستمرار إلى التميز في تقديم الخدمة للجمهور" بمتوسط حسابي (3.53) وانحراف معياري (0.883)، بينما جاءت أدنى الفقرات كالآتي: - يحصل الموظفون على مكافآت تتاسب تتييمهم، بمتوسط حسابي (2.36) وانحراف معياري (1.13). 
- - تتيح المؤسسة فرص ابتعاث الموظفين المتميزين لديها، بمتوسط حسابي (2.52) وانحراف معياري (1.17).

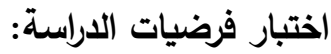

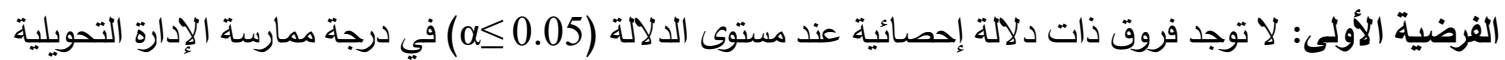
ودورها في تحقيق التميز المؤسسي من وجهة نظر العاملين في مديريات التربية والتعليم في محافظة الخليل وفق

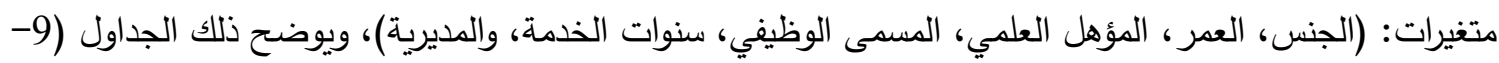

جدول(9): نتائج اختبار "ت" لدلالة الفروق في ممارسة الإدارة التحويلية وتحقيق التميز المؤسسي تبعاً لمتغير الجنس التس

\begin{tabular}{|c|c|c|c|c|c|c|c|}
\hline الإحصائية & قيمة ت & الحرية & الانعراف المعياري & المتوسط & العدد & الجنس & المجال \\
\hline \multirow{2}{*}{00.016} & \multirow{2}{*}{2.447} & 71 & 0.699 & 3.21 & 72 & ذكر & \multirow{2}{*}{ ممارسة الإدارة التحويلية وتحقيق } \\
\hline & & 30 & 0.646 & 2.85 & 31 & أنثى & \\
\hline
\end{tabular}

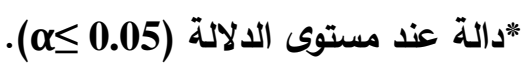
بالنظر إلى جدول (9) يتضح أن نتائج الدراسة أظهرت وجود فروق الدهات ذات دلالة إحصائية في ممارسة الإدارة التحويلية

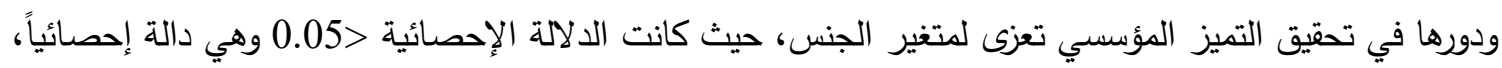
وكانت الفروق لصالح الذكور بمتوسط حسابي (3.21) مقابل (2.85) للإناث، ويعزو الباحث السبب في ذلكئ إلى الصى زيادة عدد الذكور في العينة الدراسية مقارنة بعدد الإناث.

جدول (10): المتوسطات الحسابية والانحرافات المعيارية، ونتائج اختبار"ف"، ونتائج اختبار تحليل التباين الأحادي لالالة الفروق في ممارسة الإدارة التحويلية ودورها في تحقيق التميز المؤسسي تبعا لمتغير : المؤهل العلمي

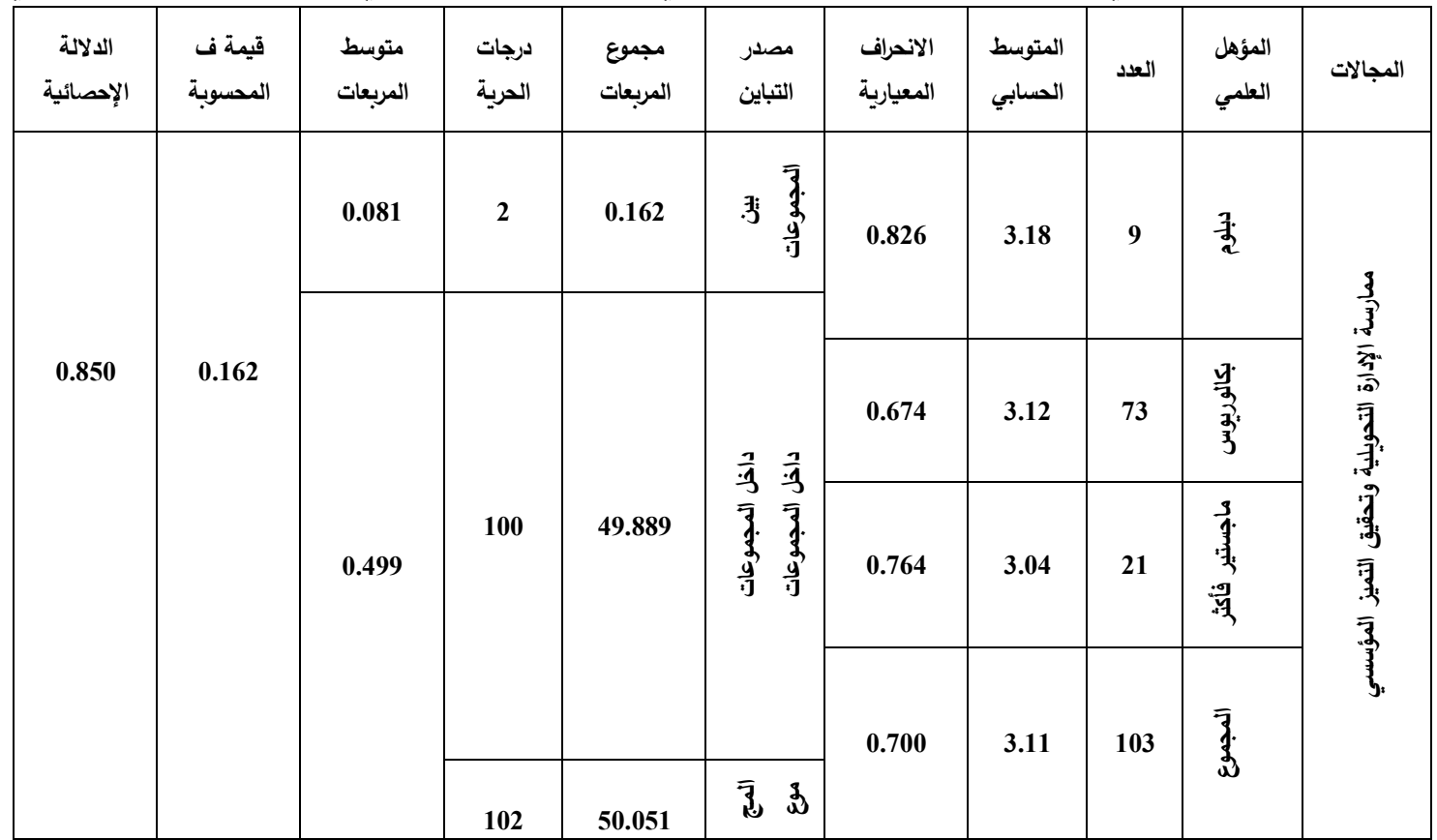

بالنظر إلى جدول (10) يتضح أن نتائج الدراسة أظهرت عدم وجود فروق ذات دلالة إحصائية في ممارسة الإدارة التحويلية ودورها في تحقيق التميز المؤسسي تعزى لمتغير المؤهل العلمي، حيث كانت الدلالة الإحصائية >0.05 
وهي غير دالة إحصائياً، ويعزو الباحث السبب في ذلك إلى أن العاملين يخضعون لنفس الأنظمة والقوانين والتعليمات بغض النظر عن مؤهلاتهم العلمية.

جدول(11): المتوسطات الحسابية والانحرافات المعيارية، ونتائج اختبار"ف"، ونتائج اختبار تحليل التباينالأحادي لالالة الفروق في درجة ممارسة الإدارة التحويلية ودورها في تحقيق التميز المؤسسي تبعا لمتغير : سنوات الخدمة

\begin{tabular}{|c|c|c|c|c|c|c|c|c|c|c|}
\hline الإحصائية & قليمة ف & متوبعط & لدرجية & المربعات & مصدر & الالانحراف & الحسابي & العدد & سنوات & الدجالات \\
\hline \multirow{5}{*}{0.086} & \multirow{5}{*}{2.260} & 1.070 & 3 & 3.209 & 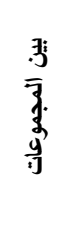 & 0.595 & 3.42 & 10 & 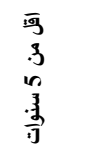 & \multirow{5}{*}{ 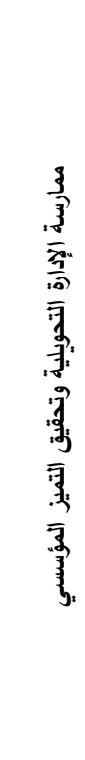 } \\
\hline & & \multirow{4}{*}{0.473} & \multirow{3}{*}{99} & \multirow{3}{*}{46.842} & \multirow{3}{*}{$\begin{array}{l}\frac{2}{3} \\
\overline{3} \\
\frac{3}{3} \\
\frac{9}{1}\end{array}$} & 0.785 & 2.83 & 25 & 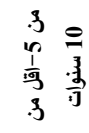 & \\
\hline & & & & & & 0.749 & 3.13 & 19 & 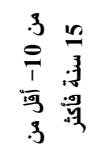 & \\
\hline & & & & & & 0.624 & 3.18 & 49 & $\begin{array}{l}3 \\
\frac{3}{6} \\
\frac{3}{3}\end{array}$ & \\
\hline & & & 102 & 50.051 & 矛 & 0.700 & 3.11 & 103 & 京. & \\
\hline
\end{tabular}

بالنظر إلى جدول (11) يتضح أن نتائج الدراسة أظهرت عدم وجود فروق ذات دلالة إحصائية في درجة ممارسة الإدارة التحويلية ودورها في تحقيق التميز المؤسسي تعزى لمتغير سنوات الخدمة، حيث كانت الدلالة الإحصائية > 0.05 وهي غير دالة إحصائياً، ويعزو الباحث السبب في ذلك إلى أن العاملين يخضعون لنفس الأنظمة والقوانين والتعليمات بغض النظر عن سنوات خدمتهم. جدول(12): المتوسطات الحسابية والانحرافات المعيارية، ونتائج اختبار"ف"، ونتائج اختبار تحليل التباين الأحادي لدلالة الفروق درجة ممارسة الإدارة التحويلية ودورها في تحقيق التميز المؤسسي تبعا لمتغير : العمر.

\begin{tabular}{|c|c|c|c|c|c|c|c|c|c|c|}
\hline الإحصائية & قليمة ف & متوسط & الحرجية & المربعات & هصدبر & المعياري & الحسابي & العدد & العمر & المجالات \\
\hline \multirow{4}{*}{0.532} & \multirow{4}{*}{0.739} & \multirow[t]{2}{*}{0.365} & \multirow[t]{2}{*}{3} & \multirow[t]{2}{*}{1.096} & \multirow{2}{*}{ 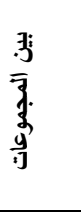 } & 1.08 & 3.21 & 8 & 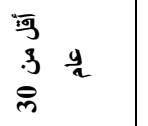 & \multirow{4}{*}{ 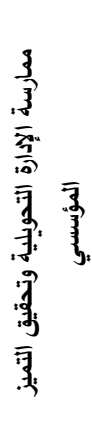 } \\
\hline & & & & & & \multirow{2}{*}{0.746} & \multirow{2}{*}{2.98} & \multirow{2}{*}{40} & \multirow{2}{*}{$\begin{array}{ll}3 & 3 \\
8 & 3 \\
0 & 9 \\
\frac{1}{i g} & \frac{9}{2}\end{array}$} & \\
\hline & & \multirow[b]{2}{*}{0.499} & \multirow[b]{2}{*}{99} & \multirow[b]{2}{*}{48.955} & \multirow{2}{*}{$\begin{array}{l}\frac{3}{3} \\
\overline{3} \\
\overline{3} \\
\text { a } \\
\frac{9}{3}\end{array}$} & & & & & \\
\hline & & & & & & 0.614 & 3.21 & 37 & 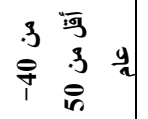 & \\
\hline
\end{tabular}




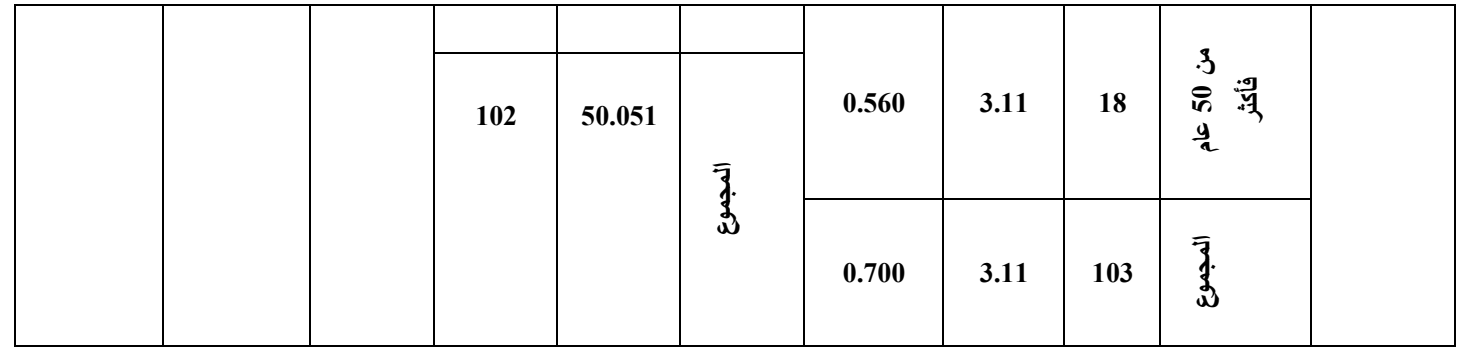

بالنظر إلى جدول (12) يتضح أن نتائج الدراسة أظهرت عدم وجود فروق ذات دلالة إحصائية في درجة

ممارسة الإدارة التحويلية ودورها في تحقيق التميز المؤسسي تعزى لمتغير العمر، حيث كانت الدلالة الإحصائية >

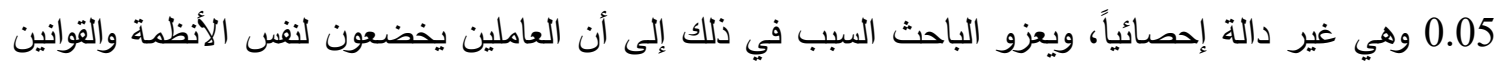
والتعليمات بغض النظر عن أعمارهم. جدول(13): المتوسطات الحسابية والانحرافات المعيارية، ونتائج اختبار"ف"، ونتائج اختبار تحليل التباين الأحادي

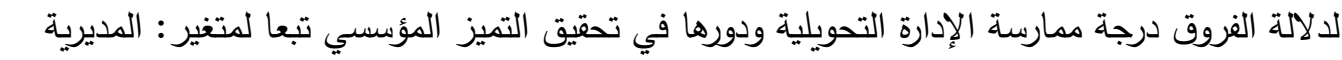

\begin{tabular}{|c|c|c|c|c|c|c|c|c|c|c|}
\hline الإلالالة & قالحسمة فة & متوبط & الحرية & المربعات & مصدر & المعيارية & الحسابي & العدد & الديرية & المجالات \\
\hline \multirow{5}{*}{0.399} & \multirow{5}{*}{0.994} & \multirow[t]{2}{*}{0.488} & \multirow[t]{2}{*}{3} & \multirow[t]{2}{*}{1.463} & \multirow{2}{*}{ 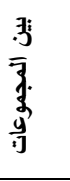 } & 0.642 & 3.16 & 24 & 罗 & \multirow{5}{*}{ 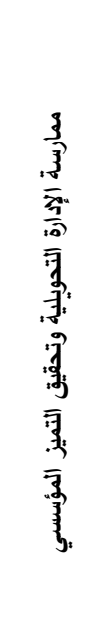 } \\
\hline & & & & & & 0.673 & 2.94 & 23 & $\overline{7}$ & \\
\hline & & \multirow{3}{*}{0.491} & \multirow[t]{2}{*}{99} & \multirow[t]{2}{*}{48.588} & \multirow[t]{2}{*}{$\begin{array}{l}\frac{7}{3} \\
\overline{3} \\
\frac{3}{3} \\
\frac{9}{10}\end{array}$} & 0.735 & 3.05 & 30 & $\frac{1}{3}$ & \\
\hline & & & & & & 0.732 & 3.27 & 26 & $\mathrm{~J}^{\prime \prime}$ & \\
\hline & & & 102 & 50.051 & 柔 & 0.700 & 3.11 & 103 & 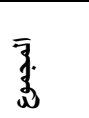 & \\
\hline
\end{tabular}

بالنظر إلى جدول (13) يتضح أن نتائج الدراسة أظهرت عدم وجود فروق ذات دلالة إحصائية في درجة ممارسة الإدارة التحويلية ودورها في تحقيق التميز المؤسسي تعزى لمتغير المديرية، حيث كانت الدلالة الإحصائية > 0.05 وهي غير دالة إحصائياً، ويعزو الباحث السبب في ذلك إلى أن العاملين يخضعون لنفس الأنظمة والقوانين والتعليمات في كافة المديريات في محافظة الخليل، حيث مصدر التعليمات واحد وهو وزارة التربية والتعليم العالي. الفرضية الثانية: لا توجد علاقة ذات دلالة إحصائية عند مستوى الدلالة (0.05 التحويلية ودورها في تحقيق التميز المؤسسي من وجهة نظر العاملين في مديريات التربية والتعليم في محافظة الخليل. 
جدول(14): معامل الارتباط لبيان العلاقة بين ممارسة الإدارة التحويلية وتحقيق التميز المؤسسي 103

\begin{tabular}{|c|c|c|c|}
\hline & & \multicolumn{2}{|c|}{ المتغيرات } \\
\hline$* * 0.651$ & معامل الارتباط & \multirow{2}{*}{ تحقيق التميز المؤسسي } & \multirow{2}{*}{ التأثير المثالي } \\
\hline 0.000 & الدلالة الإحصائية & & \\
\hline$* * 0.762$ & معامل الارتباط & \multirow{2}{*}{ تحقيق التميز المؤسسي } & \multirow{2}{*}{ الحفز الإلهامي } \\
\hline 0.000 & الدلالة الإحصائية & & \\
\hline ***0.714 & معامل الارتباط & \multirow{2}{*}{ تحقيق التميز المؤسسي } & \multirow{2}{*}{ استثارة التفكير } \\
\hline 0.000 & الدلالة الإحصائية & & \\
\hline$* * 0.720$ & معامل الارتباط & \multirow{2}{*}{ تحقيق التميز المؤسسي } & \multirow[t]{2}{*}{ الاعتبار الفردي } \\
\hline 0.000 & الدلالة الإحصائية & & \\
\hline **0.792 & معامل الارتباط & \multirow{2}{*}{ تحقيق التميز المؤسسي } & \multirow{2}{*}{ الإدارة التحويلية } \\
\hline 0.000 & الدلالة الإحصائية & & \\
\hline
\end{tabular}

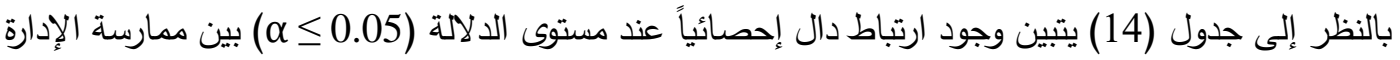

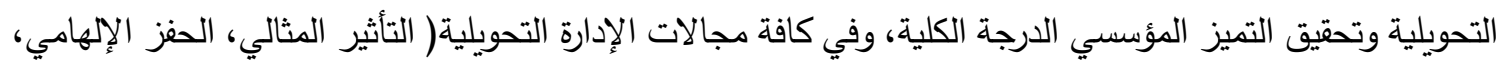

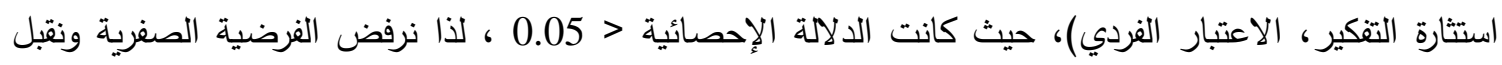

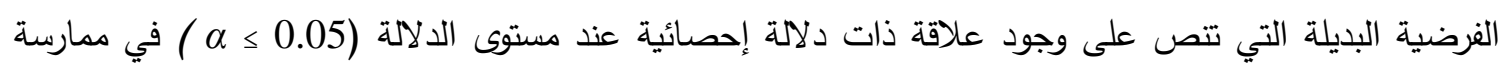
الإدارة التحويلية ودورها في تحقيق التميز المؤسسي. لعيله نتائج الاراسة: أظهرت الدراسة عدداً من النتائج منها: 1. أن درجة ممارسة الإدارة التحويلية من وجهة نظر العاملين في مديريات التربية والتعليم في محافظة الخليل من وجهة نظر المرؤوسين كانت متوسطة على الدرجة الكلية وفي كافة مجالاتها (التأثير المثالي، الحفز الإلهامي، استثارة التفكير ، الاعتبار الفردي). 2. إن أعلى مجالات ممارسة الإدارة التحويلية كان مجال استثارة التفكير، تلاه مجال الحفز الإلهامي، تلاه التأثير المثالي وأخيراً مجال الاهتمام الفردي. 3. أظهرت النتائج أن المسؤول يهتم بإعطاء الحوافز للقيام بالتغيير ، كما أنه يعطي معنى للعمل من خلال تحفيزه

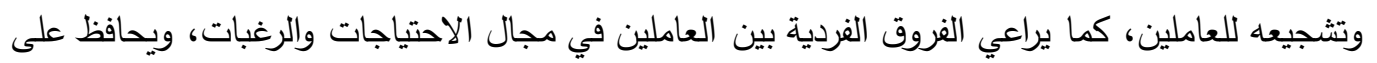

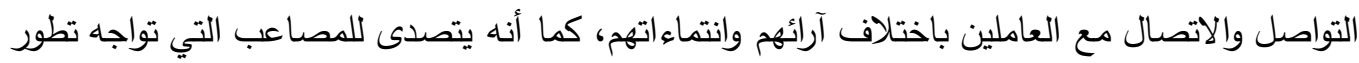
العمل بشجاعة، ويعطي الوقت الكافي للاستماع لأفكار العاملين، ويعمل على استثارة التتكير لحل المشكلات. 4. في حين بينت النتائج أن المسؤول يتعامل بثكل غير مرضي مع العاملين، كم أنه لا يثير التحدي والثبات في العاملين، ولا يثق بالجميع بقدر كبير ، ولا يباشر عملية تفويض العمل، للاطمئنان على سير العمل ونجاحها.

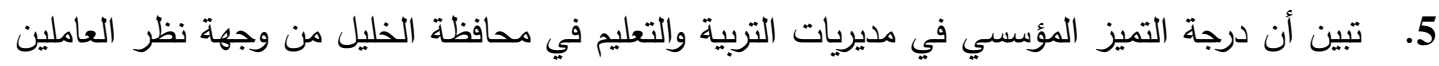

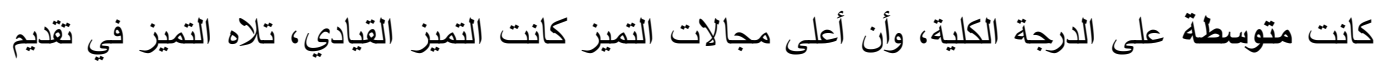

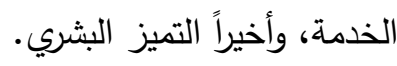
6. تبين أن إدارة المؤسسة تسعى باستمرار إلى التميز في تقديم الخدمة للجمهور . 
7. تبين أن الموظفون لا يحصلون على مكافآت تتاسب تقييمه، ولا تتيح المؤسسة فرص ابتعاث الموظفين المتميزين لديها. 8. أظهرت نتائج الدراسة عدم وجود فروق ذات دلالة إحصائية في درجة ممارسة الإدارة التحويلية ودورها في

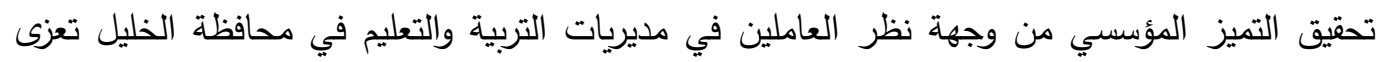
لمتغيرات: المؤهل العلمي، العمر ، سنوات الخدمة، والمديرية. في حين تبين وجود فروق ذات ذات دلالة إحصائية

$$
\text { حسب متغير الجنس وكانت الفروق لصالح الذكور . }
$$

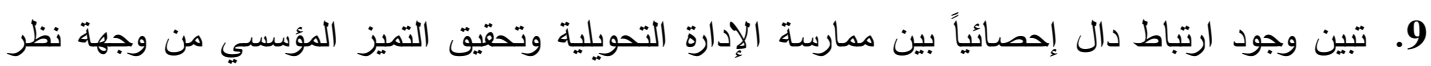
العاملين في مديريات التربية والتعليم في محافظة الخليل على الدرجة الكلية، وفي كافة مجالات الإدارة التحويلية (التأثير المثالي، الحفز الإلهامي، استثارة التفكير ، الاعتبار الفردي).

توصيات الاراسة:

في ضوء نتائج الدراسة وأهدافها، يوصي الباحث بما يلي: 1

2

3

4

5

6

7

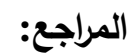

أبو هداف، سامي. (2011):" دور الإدارة التحويلية في تطوير فعالية المعلمين التدريسية بمدارس وكالة الغوث الدولية بمحافظات غزة، (رسالة ماجستير غير منشورة)، جامعة الأزهر ، غزة، فلسطين.

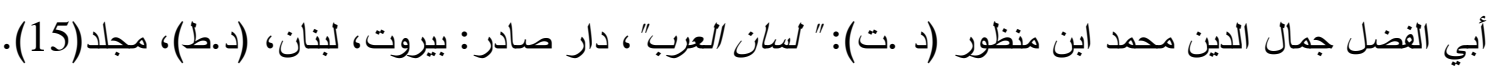
إدريس، وائل محمد صبحي؛ والغالبي، ظاهر محسن منصور • (2009). " إدارة الأداء الإستراتيجي: أساسيات الأداء وبطاقة التقييم المتوازن": دار وائل للنشر والتوزيع، عمان، الأردن.

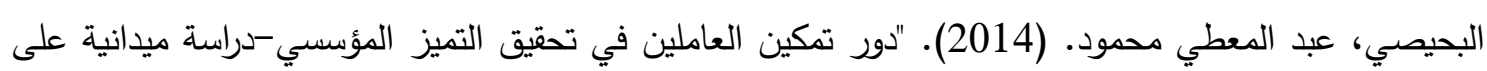

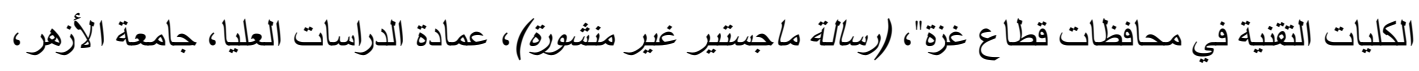
غزة، فلسطين. بني عيسى، أحمد. (2005):" أثر الإدارة التحويلية على الأداء في المؤسسات العامة في الأردن، (رسالة ماجستير غير منشورة)، كلية الدراسات العليا، الجامعة الأردنية، الأردن.

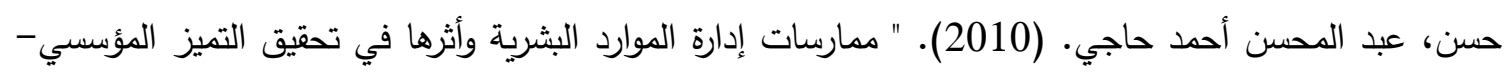
دراسة تطبيقية في شركة زين الكويتية للاتصالات الخلوية"، (رسالة ماجستير غير منشورة)، جامعة الثرق الأوسط. 
الديب، سامر كمال حامد. (2012): "مدى ممارسة القيادات الإدارية الأكاديمية بالجامعات الفلسطينية للقيادة التحويلية وصعوباتها وسبل تتميتها"، (رسالة ماجستير غير منشورة)، عمادة الدراسات العليا، كلية التربية، الجامعة بالهابة

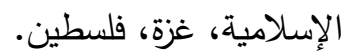

الرقب، أحمد. (2010):" علاقة الإدارة التحويلية بتمكين العاملين في الجامعات الفلسطينية بقطاع غزة، (رسالة ماجستير غير منشورة)، جامعة الأزهر ، غزة، فلسطين.

زايد، عادل محمد. (2003). "الأداء التنظيمي المتميز: الطريق إلى منظمة فلى فلى المستقبل": المنظمة العربية للتمية الإدارية، القاهرة.

العازمي. محمد. (2006):"الإدارة التحويلية وعلاقتها بالإبداع الإداري" دراسة مسحية على العاملين المدنيين بديوان وزارة الداخلية، (رسالة ماجستير غير منشورة)، السعودية.

العامري، أحمد. (2001):" السلوك القيادي التحويلي وسلوك المواطنة التظيمية في الأجهزة الحكومية السعودية"،

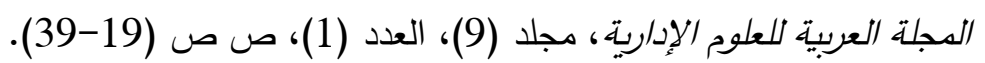

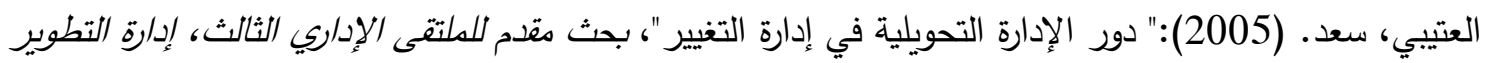
ومتطلبات التطوير في الععل الإداري (نحو إدارة متغيرة فاعلة)، جدة، السعودية.

غازي، علي علي. (2014). "الممارسات التطبيقية لمعيار الموارد والثراكات كأحد معايير الممكنات لتحقيق التميز

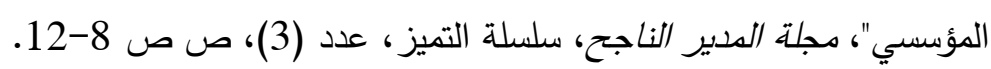

الغامدي، سعيد. (2000):"الإدارة التحويلية في الجامعات السعودية، مدى ممارستها وامتلاك خصائصها من قبل صليل

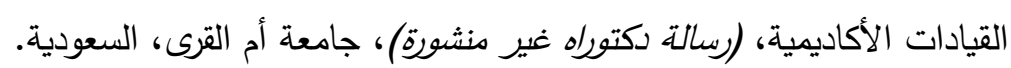

النعيمي، راتب عبد العال؛ وصويص، راتب جليل. (2008). " تحقيق الدقة في إدارة الجودة: مفاهيم وممارسات": دار اليازوري للنشر والتوزيع، عمان، الأردن.

الهلالي، الهلالي. (2001):"استخدام نظريتي الإدارة التحويلية والقيادة الإجرائية في بعض الكليات الجامعية (دراسة

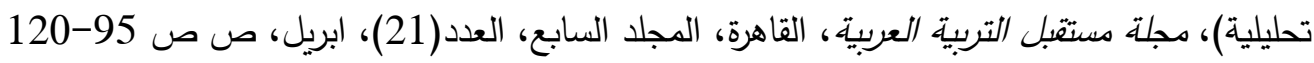

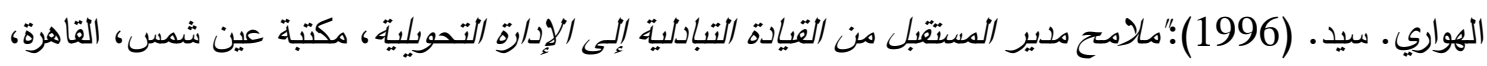
مصر

الهواري، سيد. (1999): " القائد التحويلي للعبور بالمنظمات إلى القرن ال21"، ط 2: مكتبة عين شمس، القاهرة.

\section{References}

Abu Haddaf, S. (2011). The role of transformational management in the development of the effectiveness of teachers' teaching in UNRWA schools in Gaza [Unpublished Master's thesis]. Al-Azhar University, Gaza, Palestine. (in Arabic)

Al-Amiri, A. (2001). Transformational leadership behavior and organizational citizenship behavior in Saudi Government Agencies. Arab Journal of Administrative Sciences, 9(1), 19-39. )in Arabic(

Alareeni, B., \& Deghish, H. (2016). Applicability of the balanced scorecard to assess performance of Al-Aqsa media network institution in Gaza Strip. IUG Journal of Economics and Business Studies, 24(3), 21-46. https://doi.org/10.12816/00355 
Al-Azimi, M. (2006). Transformational management and its relationship with administrative creativity: A survey study on civilian workers at the Ministry of Interior's office [Unpublished Master's thesis]. Saudi Arabia. (in Arabic)

Al-Buhaisi, A.M. (2014). The role of empowering workers in achieving institutional excellence: Field study on technical colleges in the Governorates of the Gaza Strip [Unpublished Master's thesis]. Al-Azhar University, Gaza, Palestine. (in Arabic)

Al-Deeb, S. (2012). The extent of academic administrative leaderships practicing transformational leadership in Palestinian universities, its difficulties and ways to develop it [Unpublished Master's thesis]. College of Education in Islamic University, Gaza, Palestine. (in Arabic)

Al-Ghamdi, S. (2000). Transformational management in Saudi Universities: The extent of its practice and the ownership of its characteristics by academic leaders [Unpublished Doctoral dissertation]. Umm Al-Qura University, Saudi Arabia. (in Arabic)

Al-Hawari, S. (1996). The features of the future director from transactional leadership to transformational management. Cairo, Egypt: Ain Shams Library. (in Arabic)

Al-Hawari, S. (1999). Transformational leader for transforming organizations into the 21 st Century ( $2^{\text {nd }}$ Ed.). Cairo, Egypt: Ain Shams Library. (in Arabic)

Al-Hilali, H. (2001). The use of theories of transformational management and procedural leadership in some academic faculties (an analytical Study). Journal of the Future of Arab Education, 7(21), 95-120. (in Arabic)

Al-Nuaimi, R., \& Suweis, R. (2008). Achieving accuracy in quality management: Concepts and practices. Amman, Jordan: Al Yazuri Publishing and Distribution House. (in Arabic)

Al-Otaibi, S. (2005). The role of transformational management in managing change [Conference presentation]. Third management Forum, Development Management and Development Requirements in Administrative Work (Towards Effective Change Management), Jeddah, Saudi Arabia. (in Arabic)

Alqallaf, H., \& Alareeni, B. (2018). Evolving of selected integrated reporting capitals among listed Bahraini banks. Journal of Accounting and Applied Business Research, 1(1), 1-21. https://doi.org/10.51325/ijbeg.v1i1.10

Al-Raqb, A. (2010). The relationship of transformational management with empowering workers in Palestinian Universities in the Gaza Strip [Unpublished Master's thesis]. Al-Azhar University, Gaza, Palestine. (in Arabic)

Bani Issa, A. (2005). The impact of transformational management on performance in public institutions in Jordan [Unpublished Master's thesis]. University of Jordan, Jordan. (in Arabic)

Borghini, E. (2013). Framework for the study of relationships between organizational characteristics and organizational innovation. The journal of Creative Behavior, 31(1), 226-289.

Burns, J. (1978). Leadership. NY: Harder \& Row.

Che-Meh, S., \& Nasurdin, M. (2009). The relationships between job resources, job demands and teachers' OCB. https://citeseerx.ist.psu.edu/viewdoc/download;jsessionid=4E1BAF85AE59D26B 9EA21414480EF18A?doi=10.1.1.595.1828\&rep=rep1\&type=pdf. 
Daft, R. (2000). Management. New York: The Dryden press.

Ghazi, A. A. (2014). Practical practices regarding the guidelines of resources and partnerships as one of the standards to achieve institutional excellence. Journal of the Successful Manager, Excellence Series, 3, 8-12. (in Arabic)

Griffith, J. (2004). Relation of principal transformational leadership to school staff job satisfaction, staff turnover, and school performance. Journal of Educational Administration, 42 (3), 333-356. https://doi.org/10.1108/09578230410534667

Groves, E. (1996). The effects of transformational leadership behavior of principals of National Blue Ribbon Secondary Schools in Cuyahoga County, Ohio [Unpublished Doctoral dissertation]. University of Akron.

Hasan, A. (2010). Human resource management practices and their impact on institutional excellence: An applied study in Zain Kuwaiti Mobile Telecommunications Company [Unpublished Master's thesis]. Middle East University. (in Arabic)

Hatian, W., \& Irawan, H. (2015). The analysis of organization performance using balanced scorecard at PT. Bank JabarBanten. Full Paper Proceeding GTAR-2015, Indonesia, 2, 372-382.

Howell, J. M., \& Avolio, B. J. (1993). Transformational leadership, transactional leadership, locus of control, and support for innovation: Key predictors of consolidated-business-unit performance. Journal of Applied Psychology, 78(6), 891-902. https://doi.org/10.1037/0021-9010.78.6.891

Ibn Manzur, Abu Al-Fadel Jamal al-Din. (n.d). Lisan Al Arab (Vol 15). Beirut, Lebanon: Dar Sader. (in Arabic)

Idris, W., \& Ghaleby, T. (2009). Strategic performance management: Fundamentals of performance and balanced scorecard. Amman, Jordan: Dar Wael Publishing and Distribution House. (in Arabic)

Kim, J. (2010). Strategic human resource practices: Introducing alternatives for organizational performance improvement in the public sector. Public Administration Review, 70(1), 38-49. https://doi.org/10.1111/j.15406210.2009.02109.x

Musa, P., \& Tulay, G. (2008). Investigating the impact of organizational excellence and leadership on business performance: An exploratory study of Turkish firms. SAM Advanced Management Journal, 73(1), 29-45. (in Arabic)

Owens, R. (1995). Organizational behavior in education ( $5^{\text {th }}$ Ed.). Boston, Massachusetts: Allyn and Bacon.

Pinar, M., \& Girard, T. (2008). Investigating the impact of organizational excellence and leadership on business performance: An exploratory study of Turkish firms. SAM Advanced Management Journal, 73(1), 29-45.

Zayed, A. (2003). Outstanding performance: The road to future organization. Cairo: Arab Organization for Administrative Development. (in Arabic) 